\author{
DEPARTAMENTO DE CIÊNCIAS SOCIAIS \\ Curso de Especialização em Cultura do Consumo
}

Broadcast yourself: como um youtuber se torna um influenciador digital

Juliana de Souza Mol

Orientadora: Prof ${ }^{\mathrm{a}}$ Alessandra Terra Maia de Faria 


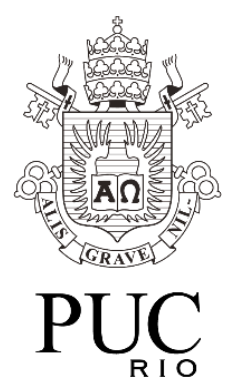

Juliana de Souza Mol

\section{Broadcast yourself: como um youtuber se torna um influenciador digital}

Monografia apresentada à Coordenação Central de Extensão da PUC-Rio como requisito parcial para conclusão do curso de especialização Cultura do Consumo, do departamento de Ciências Sociais.

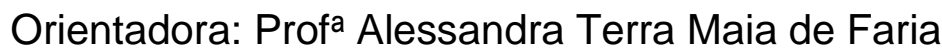

Rio de Janeiro

Abril de 2018 


\section{Agradecimentos}

Agradeço imensamente ao meu pai e a minha mãe pelo apoio de sempre.

A minha irmã Ana Paula pelo carinho, apoio e compreensão.

A minha sobrinha Milena por ter me ajudado com à luz necessária para a escolha do tema.

A professora Alessandra Maia, pela orientação e paciência comigo.

A Luana pelo companheirismo e paciência.

E, agradeço também a todos os demais docentes e equipe da Especialização em Cultura do Consumo.

A todos os queridos colegas de turma, sobretudo àqueles que chegaram ao final do curso e dividiram as alegrias e angústias do processo de escrita.

A todas as colegas de trabalho, principalmente o Glauber que contribuiu na construção desse Trabalho; sem cada uma dessas pessoas que eu citei essa monografia não seria possível. 


\section{Resumo}

O presente trabalho procura compreender o surgimento de uma importante plataforma e sua contribuição nas novas formas de se fazer mídia na contemporaneidade - o YouTube. E, como foco de pesquisa, entender por um viés analítico, o nascimento de um fenômeno chamado "youtuber" e sua transformação em influenciadores do consumo. Para tanto, apresento uma análise do perfil do maior e mais influente youtuber brasileiro - Whindersson Nunes - com o intuito de detalhar características que fizeram dele a personalidade mais influente da internet em 2017. Para tanto, utilizo a netnografia que detalha como ele se apresenta para seu público, como se relaciona com as marcas e principalmente como interage com os seus seguidores.

Palavras-chave: Consumo, YouTube, youtuber, mídia e influenciadores 


\section{Abstract}

The present work seeks to understand the emergence of an important platform and its contribution in the new forms of making media in the contemporary - YouTube. And, as a research focus, to understand by an analytical bias, the birth of a phenomenon called "youtuber" and its transformation into consumption influencers. To do so, I present an analysis of the profile of the largest and most influential Brazilian youtuber - Whindersson Nunes - with the intention of detailing characteristics that made him the most influential personality of the internet in 2017. For that, I use the netnography that details how he presents himself its audience, how it relates to brands and especially how it interacts with its followers.

Keywords: Consumption, YouTube, youtuber, media and influencers 
"eu me mostro, mas isso não basta, pois o outro tem que dizer que me viu”

Paula Sibilia

(O show do eu) 


\section{LISTA DE FIGURAS}

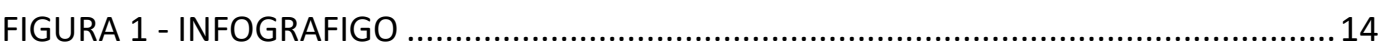

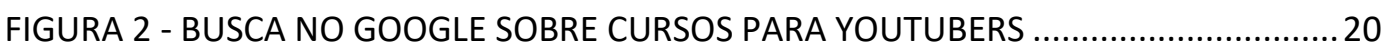

FIGURA 3 - IMAGEM DO CURSO - QUERO SER YOUTUBER …....................................... 21

FIGURA 4 - SLOGAN CAMPANHA YOUTUBE - NOVOS TEMPOS NOVOS ÍDOLOS ................22

FIGURA 5 - BANNER - CAMPANHA NOVOS TEMPOS NOVOS ÍDOLOS …..........................23

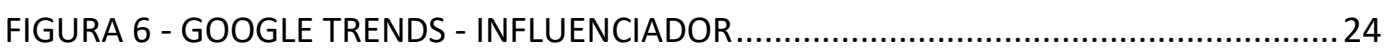

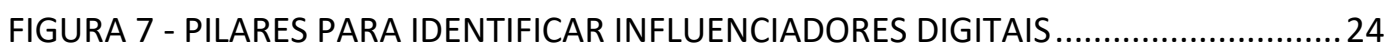

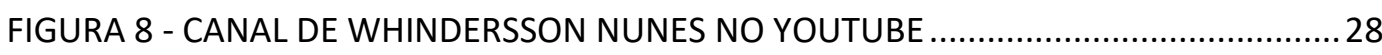

FIGURA 9 - VIDEO SOLTEIRO OU NAMORANDO - WHINDERSSON NUNES - RECORTE 0:14

31

FIGURA 10 - VIDEO SOLTEIRO OU NAMORANDO - RECORTE 00:35 ….............................. 31

FIGURA 11 - RANKING DA PESQUISA - OS INFLUENCIADORES - QUEM BRILHA NA TELA

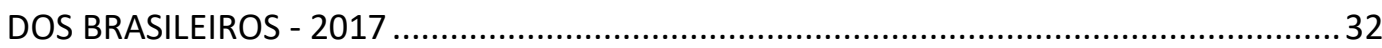

FIGURA 12 - ANALISE DE SENTIMENTO DOS COMENTÁRIOS SOBRE O VÍDEO - SOLTEIRO

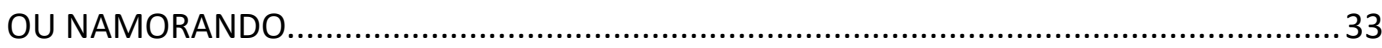

FIGURA 13 - GRÁFICO QUE REPRESENTA O NÚMERO DE COMENTÁRIOS NO VÍDEO -

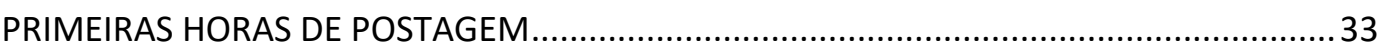

FIGURA 14 E 12 - IMITAÇÃO DO CASAL LUISA SONSA E WHINDERSSON NUNES ............. 34

FIGURA 15 - NUVEM DE CORRESPONDÊNCIA - COMENTÁRIOS VÍDEO - SOLTEIRO OU

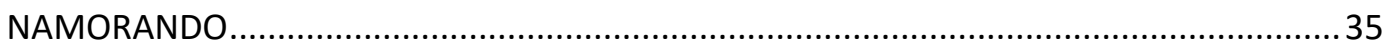

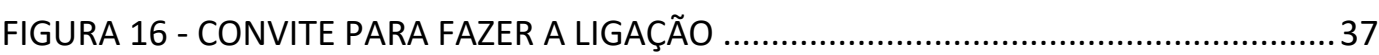

FIGURA 17 - NUVEM DE CORRESPONDENCIA - COMENTARIOS SOBRE O GOOGLE DUO. 37 


\section{Sumario}

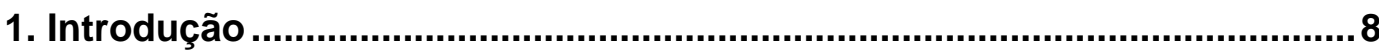

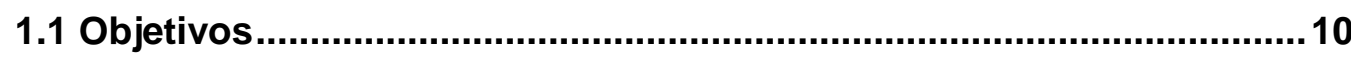

1.2 Objetivos Específicos .....................................................................10

1.3 Metodologia .................................................................................10

2. O YouTube: mais um fruto da cibercultura ...............................................11

2.1 Para uma inteligência coletiva .........................................................11

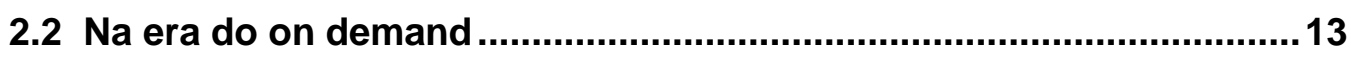

2.3 O Youtube e as mudanças na forma de fazer publicidade ..............17

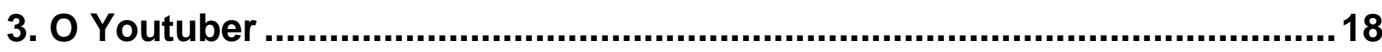

3.1 Como o youtuber se torna um influenciador digital ............................21

4. O Lampião do YouTube - Um fenômeno chamado Whindersson .........26

4.1 Sem camisa no quarto bagunçado: Da apresentação para o publico 30 4.2 O vídeo Solteiro ou Namorando ........................................................33

4.3 Com o Google Duo é cara a cara - A relação com a marca..............35

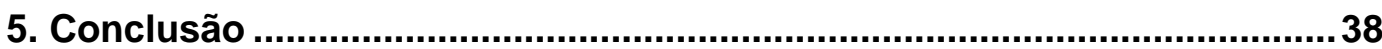

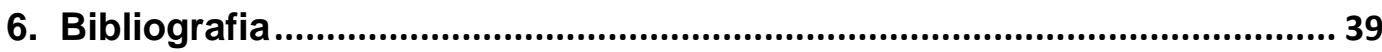




\section{Introdução}

Não é nada fácil escolher um tema para o Trabalho de Conclusão de Curso. Quando comecei o curso de pós-graduação em Cultura do Consumo, eu tinha várias ideias, mas com o passar dos meses percebi que viveria um dilema para escolher. $\mathrm{O}$ curso tinha me proporcionado uma visão diferente sobre tudo na minha vida, principalmente a respeito das relações de consumo. Conversei com os professores na busca de uma luz, mas todos me disseram que o ideal era escolher um assunto de interesse pessoal. O problema é que tudo no curso passava a ser um interesse para mim, afinal a gente lê muita coisa durante um ano e meio. Tantas ideias surgem e outras tantas se vão. O desespero começava a dar sinais. Já no meio do curso havia desistido de pelo menos uns três temas. Faltava algum estimulo. Algo mais...

Um dia fui visitar minha família que mora em Belo Horizonte. Pensava que a mudança de ares podia fazer bem para minha cabeça. Quem sabe ali eu não encontrava o que estava procurando. Pois é! Foi exatamente o que aconteceu. A ideia para o tema veio da minha sobrinha de 12 anos. Foi um momento tão magico que é preciso contar.

Sempre quando eu chego em $\mathrm{BH}$, a minha sobrinha fica atrás querendo compartilhar tudo que aconteceu na sua vida durante a minha ausência. Uma das afinidades que temos é o apreço por compartilhar conhecimento. Seja uma música nova, um livro, uma matéria nova(...). Qualquer assunto pra gente vira pauta. Dessa vez, a minha sobrinha queria me mostrar os youtubers que ela mais gostava. Confesso que até aquele momento eu não fazia ideia que a minha sobrinha entrava na internet - minha irmã é muito rígida com ela.

Empolgada, a minha sobrinha pergunta:

- Dindinha, qual canal no YouTube que você mais gosta?

- Abrindo um sorriso largo no rosto, respondi:.

- Ahhh Milena eu gosto de muitos canais, mas eu assisto com frequência o canal do Whindersson, o do Porta dos fundos e do Castanhari. E você?

Naquele momento escutei um estrondo na minha cabeça. O tema estava ali na minha cara. Vou pesquisar sobre o YouTube, mais especificamente sobre o fenômeno dos 
youtubers. Afinal eu trabalho com publicidade e lido direta e indiretamente com o assunto todos os dias.

Fico impressionada com a forma que essas pessoas constroem sua relevância nas redes, adquirindo audiências gigantescas e fidelizadas, chegando a serem reconhecidas pela própria mídia tradicional. Este é um fenômeno que ainda reserva complexidades, pois faz parte de um ainda maior, o dos "influenciadores digitais". Essa denominação que ainda fico reflexiva em decifrar, se tornou algo bastante popular para designar qualquer pessoa que agrega grande número de seguidores nas redes, ou seja, um potencial formador e influenciador de opiniões. Surgindo nas mais diversas mídias possíveis, essas pessoas se tornam alvo de marcas em busca de mediação para as suas mensagens e assim fazem da produção de conteúdos uma profissão.

Para mim, é completamente incrível que através do uso da Internet, das redes sociais e com poucos recursos materiais, pessoas anônimas se tornam amplamente conhecidas sem nem mesmo sair de casa. Com a fidelização dos públicos, elas passam a ser acompanhadas diariamente em suas redes sociais, se tornando íntimas de seus seguidores e se expondo vinte e quatro horas por dia.

Dentre as vertentes de profissionais contemporâneos da web, selecionei os youtubers por estes serem os protagonistas da maior plataforma para o consumo audiovisual do mundo; um destino diário de pessoas em busca de informação e entretenimento.

A presente monografia se debruça, em alguma medida, sobre o fenômeno dos youtubers na sociedade contemporânea, por ser um tema pouco explorado por estudiosos no Brasil e principalmente, por estudiosos da Ciências Sociais. A monografia se divide em três partes. A primeira parte discorro sobre o nascimento da plataforma YouTube e sua contribuição nas novas formas de se fazer mídia na contemporaneidade. $\mathrm{Na}$ segunda parte, explicou o surgimento dos chamados youtuber - produtores de conteúdo da plataforma e sua transformação em influenciadores do consumo. Por último, apresento uma análise do perfil do maior e mais influente youtuber brasileiro - Whindersson Nunes - afim de detalhar como um youtuber se apresenta para seu público, como se relaciona com as marcas e principalmente como interage com os seus seguidores. 


\subsection{Objetivos}

O presente trabalho tem como objetivo principal, fazer uma breve análise da plataforma YouTube e a transformação dos produtores de conteúdo em influenciadores digitais - youtubers. Entender como esses se apresentam, como se relacionam com as marcas que o patrocinam e como interagem com os seus seguidores.

\subsection{Objetivos Específicos}

- Analisar a importância das produções audiovisuais para a sociedade contemporânea e como a plataforma do Youtube modificou a comunicação e o marketing;

- Fazer um mapeamento sobre a atuação mercadológica dos influenciadores digitais criadores de conteúdo focados no site Youtube;

- Realizar um estudo disruptivo a partir da análise netnografica do canal Whindersson Nunes na plataforma do YouTube. E, em alguma medida explicar a sua trajetória a partir de três pontos: apresentação, relacionamento com a marca e interação com o público.

\subsection{Metodologia}

Como método de pesquisa indicado para analisar o comportamento de nas comunidades virtuais geradas e mantidas por usuários da Internet (KOZINETS, 1998), o presente estudo, de caráter exploratório e natureza qualitativa, pretende utilizar a metodologia Netnográfica ou, também, conhecida como Etnografia digital, para investigar o comportamento dos seguidores que assistem os canais de de um famoso influenciador youtuber - Whindersson Nunes. A escolha da aplicação dessa metodologia, justifica-se pela sua característica técnica qualitativa e, por ser a mais apropriada para estudar conexões, motivações e comportamentos em comunidades virtuais orientadas para consumo (KOZINETS, 2002), mas ela é ainda a mais indicada, principalmente, por se concentrar na interpretação da cultura a partir de descrições de fatos observados e nas motivações e significados de discursos online. Isso permite uma melhor compreensão do fenômeno investigado. Também apoiamos o trabalho na pesquisa documental que possui semelhanças com a bibliográfica, diferenciando-se apenas quanto à natureza das fontes, pois a 
primeira se vale de materiais que ainda não receberam um olhar analítico e que podem ser reelaborados de acordo com o objeto da pesquisa. Neste sentido, usaremos artigos disponíveis na mídia, assim como pesquisas e sondagens de instituições reconhecidas no mercado.

\section{O YouTube: mais um fruto da cibercultura}

\subsection{Para uma inteligência coletiva}

A Era da Informação, de maneira geral, constitui o novo momento histórico cuja base de todas as relações se estabelece através da informação, da sua capacidade de processamento e de geração de conhecimentos. Para o sociólogo Manuel Castells (1999) isso é a composição "sociedade em rede", que tem como alicerce o advento da Internet com seus usos e todos os seus aspectos positivos e negativos incorporados pela sociedade contemporânea. Já para o filosofo e também sociólogo Pierre Levy (1999), a sociedade em rede tem um outro nome: a "cibercultura", que por sua vez submerge no ciberespaço. O [ciberespaço] especifica não apenas a infraestrutura material da comunicação digital, mas também o universo oceânico de informação que ela abriga, assim como os seres humanos que navegam e alimentam esse universo. Quanto ao neologismo "cibercultura", "entende-se muito mais como o conjunto de técnicas (materiais e intelectuais), de práticas, de atitudes, de modos de pensamento e de valores que se desenvolvem juntamente com o crescimento do ciberespaço" (LÉVY, 1999, pg. 17).

Assim, estaríamos passando por um processo de universalização da cibercultura, na medida em que estamos dia-a-dia mais imersos nas novas relações de comunicação e produção de conhecimento. Ainda sim, vale lembrar que mesmo vivendo um momento de estado global da informação e com o avanço da ciência da tecnologia, o acesso da internet ainda se encontra restrito em muitos lugares do mundo, inclusive por questões políticas. Mas de um modo geral, o ciberespaço possibilita o surgimento de diferentes formas de sociabilidade e suas práticas - positivas e negativas - em sua forma mais complexa.

O ciberespaço é orientado por três princípios fundamentais: a interconexão, a criação de comunidades virtuais e a inteligência coletiva. A interconexão, mundial ou local, é um princípio básico do ciberespaço, na medida em que sua dinâmica é 
dialógica. Já as comunidades virtuais "são construídas sobre afinidades de interesses, de conhecimentos, sobre projetos, em um processo mútuo de cooperação e troca" (LÉVY, 1999, pg.127). E o terceiro princípio é a inteligência coletiva, que pode ser considerada a finalidade última do ciberespaço, pois ela descreve um tipo de inteligência compartilhada que surge da colaboração de muitos indivíduos em suas diversidades. "É uma inteligência distribuída por toda parte, na qual todo o saber está na humanidade, já que, ninguém sabe tudo, porém todos sabem alguma coisa” (LÉVY, 2007, pg. 212).

Neste trabalho, foi imprescindível analisar o YouTube dentro da lógica da cibercultura e do ciberespaço como uma plataforma baseada na democratização da informação e do compartilhamento dos saberes que, por sua vez amplia o princípio da inteligência coletiva, assim como potencializa novas formas de comunicação.

No ano de 2017 foi divulgada pela Secretaria de Comunicação Social da Presidência da República, uma pesquisa chamada Pesquisa Brasileira de Mídia 2016 (PBM 2016) $^{1}$ que descreve os hábitos de consumo das mídias no Brasil. E diferentemente de alguns anos atrás, a pesquisa revelou que o hábito de uso da internet aumentou e a população brasileira já passa mais tempo online do que assistindo televisão. Pouco mais que a metade dos brasileiros já faz uso constante da internet, chegando a passar cerca de cinco horas conectados durante os dias da semana. Já o percentual de pessoas que utilizam a internet todos dos dias cresceu mais de 10\% em comparação à mesma pesquisa realizada em 2015 (37\%), passando para 50\% em 2016. Dos brasileiros que utilizam a internet, $67 \%$ deles o fazem em busca de entretenimento, razão de uso que ocupa o primeiro lugar - junto à busca por informações/notícias. Em seguida, encontram-se o uso para: passatempo (38\%) e estudos/educação (24\%). Houve também um aumento da participação em redes sociais. Os internautas que costumam navegar pela internet todos os dias (93\%) estão presentes nas redes sociais. Segundo o Google Insights e o site de mensuração de audiência para plataformas digitais - ComScore - no Brasil, 95\% da população online acessa Youtube ${ }^{2}$ pelo menos uma vez por mês. São 98 milhões de brasileiros

\footnotetext{
${ }^{1}$ http://pesquisademidia.gov.br/\#/Geral/details-917 - acessado em 10/03/2018

2 http://comscore.com Relatório do COMSCORE MULTI-PLATFORM, 2014-2017
} 
conectados. O YouTube tem mais de $94 \%$ de penetração nas classes A, B e C. Os millennials (96\%) dos jovens de 18 a 35 são os que mais acessam a plataforma ${ }^{3}$.

No que tange aos usos internos dentro da plataforma, a maioria busca conteúdos que não estão disponíveis em outros meios como, por exemplo na televisão. Esses dados, demostram uma mudança no paradigma do consumo e distribuição de mídia pela qual a sociedade tem passado nas últimas décadas. Sem dúvida, as inúmeras formas graças a internet e as tecnologias, possibilitaram com que as pessoas mudassem a maneira de assistir conteúdos audiovisuais em geral. Hoje, nós como consumidores de conteúdo, preferimos os que são adaptáveis a nossa rotina e as nossas necessidades momentâneas e, além disso, temos a possibilidade de produzir e distribuir os nossos materiais online no momento que quisermos.

\subsection{Na era do on demand}

Esse comportamento, está intimamente ligado ao surgimento de plataformas de streaming - uma tendência que se deve a grande demanda dos usuários que desejam assistir - seja a uma novela, filme, série, reportagem, vídeo-aula, vídeo humorístico, etc. - no horário e momento em que têm disponibilidade, o chamado on demand. A despeito dessa tendência, grandes emissoras estão lançando aplicativos que possibilitam o consumidor assistir o conteúdo da televisão na hora que quiser. Para tanto, é preciso assinar uma mensalidade. Mas, o Youtube ainda assume posição privilegiada por abarcar uma enorme diversidade de conteúdos gratuitos, oferecer esse tipo de serviço, tornando-se uma plataforma de referência.

\footnotetext{
${ }^{3}$ https://www.thinkwithgoogle.com/intl/pt-br/youtubeinsights/2017/de-play-em-play/ - Dados revelados pela Pesquisa Google e Reds com Consumidores Brasileiros Online - Maio de 2017.
} 


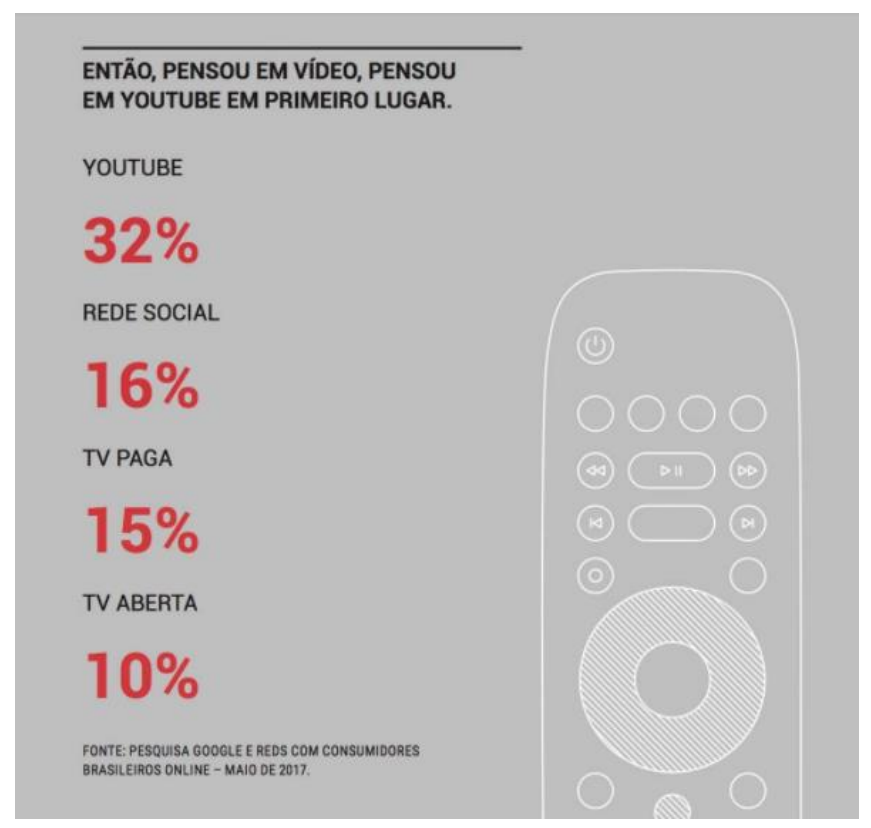

Figura 1 - INFOGRAFIGO

Conforme a figura 1 - o YouTube é a principal plataforma a ser lembrada por aqueles que busca de entretenimento em vídeo, como espaço para a divulgação e monetização de conteúdo audiovisual. O Brasil é um país que tem se destacado nesse mercado, tanto produzindo quanto consumindo conteúdo. De acordo com a própria plataforma, os brasileiros assistem a cerca de 15 horas de conteúdos em vídeo na internet por semana, o que classifica o país como o segundo lugar em visualizações no Youtube, perdendo apenas para os Estados Unidos. Já no que se refere a produção de conteúdo, temos mais de 300 mil canais atuantes.

Sem dúvidas, fatores que alavancaram o crescimento e o interesse do audiovisual no Brasil foram o barateamento e a expansão tecnológica dos dispositivos moveis como celulares e tabletes. Segundo a Pesquisa brasileira de mídia de 2016, houve um aumento significativo no uso dos dispositivos moveis como principal meio de acesso à internet. Sendo $72 \%$ acessando via celulares e tabletes contra $25 \%$ do acessando à internet via computadores e notebooks.

Com o avanço das tecnologias de informação e comunicação e o crescimento vertiginoso das redes sociais nos últimos anos, temos visto cada vez mais uma mudança no modo de pensar e de ver o mundo que nos cerca. Hoje, temos a 
capacidade de conexão uns com os outros sem precedentes que derrubam fronteiras, cria um fluxo de informação orgânico 24 horas por dia e um alto poder de decisão do que desejamos ou não consumir. Além disso, chegamos a uma era que qualquer pessoa pode ser produtor conteúdo, criador de tendências ou até mesmo se tornar uma referência social. Um fenômeno bastante emblemático que faz parte dessa mudança no consumo de informação é o YouTube.

Cidadãos com acesso à rede podem disponibilizar online aquilo que consideram pertinente, e essas publicações podem ser acessadas por poucos, mas com potencial de circulação que permite alcançar grande volume de acessos. "A modernidade libertou o homem das tradições que eram divinamente estabelecidas. O homem passou a ser soberano" (HALL, 1998, pg. 23).

O YouTube foi criado em 2005 por Chad Hurley, Steve Chen e Jawed Karim. A ideia inicial era fazer do site um tipo de repositório de vídeos on-line com a capacidade de "armazenar" ou hospedar vídeos caseiros dos usuários. Em 2006, mais ou menos um ano depois da sua criação, a Google (a principal empresa de organização da informação mundial) fez uma oferta pela empresa e a comprou por e US\$ 1,65 bilhão. Nos anos seguintes a empresa fez grandes mudanças na plataforma, fazendo também com que seu formato inicial mudasse drasticamente de repositório de arquivo para uma plataforma social.

A plataforma é basicamente um site gratuito de upload, compartilhamento e visualização de vídeos com conteúdo gerado pelos próprios usuários. Mas, para veicular qualquer coisa no site é preciso concordar com as diretrizes em relação a direitos autorais, privacidade e segurança. De todo modo, qualquer pessoa pode postar vídeos ou fazer transmissões ao vivo. É democrático e livre - haja vista o seu significado: Youtube é derivado de dois termos, "you", que significa "você" e "tube" que seria uma gíria para "televisão", logo, numa tradução livre, seria algo como: "televisão feita por você". E, é exatamente isso o diferencial dessa plataforma social, pois ela permite partilhar e assistir a vídeos de outros usuários.

“Broadcast Yourself” é o slogan do YouTube. Em uma tradução livre em português "transmita-se" - no sentido visual - o site se define como um conector de pessoas, fazendo com que elas descubram, assistam e compartilhem vídeos todos os dias. E assim é apresentado: "acreditamos que todos mereçam ter uma voz, e que o mundo 
é um lugar melhor quando escutamos, compartilhamos e construímos a comunidade por meio de nossas histórias" (YOUTUBE, 2017).

Segundo o próprio YouTube, hoje a plataforma conta com uma diversidade de conteúdos que podem variar desde canais pessoais, de artistas da música, de produtoras, emissoras televisivas, sites de negócios, educação, entretimento e outras variedades. Porém, dentre essa, a que mais se destacam são os canais de entretenimento - suas diversas vertentes e tipos (clipes musicais, vlogs, paródias, sketches de comédia, tutoriais de dança, testes de produtos) etc.

O YouTube também lidera em humor, educação, notícias, concertos, músicas, sendo muito relacionado a entretenimento, aprendizagem e passatempo, além de ser bastante utilizado pela audiência ligada a assuntos como moda, saúde e medicina. (GOOGLE BRASIL, 2015).

Além de ser uma plataforma que preza pela democracia da informação e o incentivo da criatividade, o YouTube também é fundamental para os internautas no sentido de disponibilizar gratuitamente a divulgação dos produtos audiovisuais e principalmente por garantir uma visibilidade global. Henry Jenkins no livro Cultura da Convergência (2013) observa que "ter um site compartilhado significa que essas produções obtêm uma visibilidade muito maior do que teriam se fossem distribuídas por portais separados e isolados" e propõe

(...) compreender o YouTube como parte de uma organização cultural maior. Em primeiro lugar, o YouTube representa o encontro entre uma série de comunidades alternativas diversas, cada uma delas produzindo mídia independente há algum tempo, mas agora reunidas por esse portal compartilhado. (JENKINS, 2013, pg. 357)

Com outras palavras, mas na mesma luz trazida por Jenkins (2013) na citação acima, fica evidente que o YouTube é hoje um meio facilitador de processos de socialização, publicização e auto expressão - seja em maiores ou menores níveis dependendo do empenho de seus usuários. Ele é um espaço de pluralidades e reflexo da vida social e comercial, onde todos os tipos de produtores de conteúdo e públicos se encontram, podendo se relacionar e compartilhar experiências. Ou seja, a plataforma democratizou a distribuição de conteúdo em vídeo, redistribuindo o poder de mídia e rompendo com a lógica de emissão dos veículos de comunicação de massa (emissor-receptor). Com efeito, o consumo de mídia contemporâneo se 
caracteriza de forma diferente ao dos estudos de meios de comunicação de massa. Segundo Burgess e Green (2009), estamos em um momento que deixamos de ser meros espectadores (passivos) para nos tornar poderosos espectadores-produtores. O consumo não é mais necessariamente visto como o ponto final em uma cadeia econômica de produção, mas como uma oportunidade de inspiração para o desenvolvimento da inovação e criatividade própria do indivíduo.

\subsection{O Youtube e as mudanças na forma de fazer publicidade}

Como evidenciado nos tópicos anteriores, a dinâmica da democratização do conteúdo, o compartilhamento livre e orgânico do mesmo que rege o funcionamento do Youtube - e de outras mídias colaborativas - vai de encontro à dos veículos de comunicação de massa, entregando as ferramentas necessárias para a auto-expressão e desenvolvimento da criatividade nas mãos dos usuários. Vale ressaltar, que o funcionamento do site - próprio da dinâmica da internet possibilitou a circulação de uma quantidade imensa de informações e espaços jamais ofertados nos meios tradicionais de comunicação de massa.

"o YouTube emergiu como um site fundamental para a produção e distribuição da mídia alternativa - o marco zero, por assim dizer, da ruptura nas operações das mídias de massa comerciais, causada pelo surgimento de novas formas de cultura participativa". (JENKINS, 2013, pg. 357).

Existem várias diferenças que podemos citar entre a dinâmica do YouTube e a dos meios de comunicação tradicionais, porém, uma semelhança é inquestionável. Para se manterem vivos, ambos dependem do mercado publicitário, ou seja, do investimento de grandes marcas anunciantes. No YouTube, marcas são atraídas pela quantidade de acessos que a plataforma recebe - diferentes tipos de públicos em busca de conteúdo personalizados - que por sua vez são atraídos pelos criadores de conteúdos interessantes, os quais se mantêm criativos e ativos, em partes, por causa das diversas formas de incentivo que recebem da empresa, inclusive em forma de retorno financeiro.

Uma outra diferença da plataforma e talvez uma das principais, pois estimula a produção de conteúdo de qualidade é a "economia do alcance". A economia do alcance são os conteúdos mais acessados que constantemente são colocados em 
posição de destaque no site. Dos canais que atingirem uma marca que gira em torno de 10 mil visualizações, são convidados a participar de um seleto "Programa de Parceiros". Ao participar deste programa o canal é habilitado a veicular anúncios no início de seus vídeos, monetizando assim seu conteúdo. Outro ponto importante e, que diferencia substancialmente o YouTube dos meios tradicionais de publicidade é a experiência proporcionada, pois o público pode assistir, compartilhar e influenciar o conteúdo exibido a qualquer momento, basta um clique.

O relacionamento da plataforma com os seus usuários, principalmente os produtores de conteúdos - creators $^{4}$ - mais ativos, vão desde consultorias online, pagamento de receitas por quantidade de visualizações, convites para visitação da sede do Google em São Paulo e premiações com placas comemorativas de inscritos no canal ${ }^{5}$.

A plataforma acredita que dando o devido apoio e os incentivos constantes, fica mais fácil manter a qualidade dos creators e a frequência dos conteúdos produzidos por eles. Isso, funciona como uma mola propulsora que ajuda a movimentar o site, atrair audiência, gerar views e consequentemente a receita necessária para se manter vivo. Apesar de parecer um processo comunicacional simples, o YouTube conseguiu até o momento gerar uma verdadeira cadeia de ações com feedbacks constantes e reverberação em outras mídias, modificando consideravelmente o mercado da Comunicação e do Marketing - online e offline.

\section{O Youtuber}

Como descrevi no capítulo anterior, surgiu nos últimos anos uma grande quantidade de creators de conteúdo de vídeo focados em produzir especificamente para a plataforma YouTube. Essas pessoas foram intituladas "youtubers". No artigo The YouTuber: A Qualitative Study of Popular Content Creators de Mattias Holmbom o termo youtuber significa qualquer criador de conteúdo que se dedica bastante

\footnotetext{
${ }^{4}$ Os creators são todos os colaboradores de conteúdo do YouTube.

${ }^{5} \mathrm{O}$ site premia os seus usuários considerados relevantes, com uma placa personalizada, de acordo com a quantidade de inscritos. O YouTube reforça que considera importante reconhecer os criadores que se dedicam e conquistam sua audiência de forma legítima, respeitando as regras do site.
} 
tempo ao Youtube (HOLMBOM, 2015, pg 05 - tradução minha). Contudo, esta definição tem ganhado novas características, já que de uma maneira geral as pessoas consideram um youtuber como aqueles que postam vídeos periodicamente e constroem audiências fidelizadas, ou seja, volume de seguidores e que ganham de alguma forma com a monetização do canal. Muitos usuários do YouTube quando conseguem são convidados a participar do "Programa de Parceiros" chegam a se transformar em verdadeiras marcas, ao ponto de lucrar quantias significantes e viverem disso. Sem dúvida o YouTube e outras redes sociais, possibilitaram o nascimento de era do empreendedorismo online.

Para a antropóloga Paula Sibilia (2008), isso é fruto, também, do fenômeno de espetacularização da sociedade. Um show do eu que se faz a partir da introdução das novas mídias como o YouTube, no cotidiano da população. Para ela, trata-se da própria "democratização" dos meios, ocasionada com a superação do modelo de comunicação fundado no broadcasting, onde havia um emissor para vários receptores, para o fenômeno da comunicação de todos para todos, inicia uma era comunicacional onde todos podem ter "voz" e, ainda sim, ganhar por ela.

Muito antes do fenômeno youtuber existir, os criadores de conteúdo pareciam muito mais despretensiosos com os tipos de vídeos que compartilhavam, muitas vezes utilizando poucos equipamentos, sendo até simplista, falando para a câmara e gravando do próprio quarto - o que não deixa de ser a realidade de alguns até hoje, inclusive dos que fazem bastante sucesso. No começo, grande parte deles se inseria no mercado com produções mais simples, como forma de hobby, destacando-se o amadorismo. Porém, o que se vê nos dias atuais é uma profissionalização cada vez maior, principalmente na medida em que o número de inscritos e a visibilidade aumentam. Hoje, esses produtores de conteúdo estão preocupados com a dinâmica das suas postagens e a periodicidade e, principalmente com o conteúdo que vai atrair mais likes e inscritos. Alguns contam com uma equipe de criação, empresas de assessoria, produtoras de edição de vídeo; tornando-se verdadeiras celebridades.

Segundo Holmbom (2015) as visualizações geradas pelos youtubers se transformam em ganhos mensais e fazer vídeos para o YouTube se tornou uma maneira de ganhar dinheiro parecida com qualquer outra profissão, porém, para se estabilizar leva tempo e, é necessário a construção de uma estratégia solida. Por 
isso, surge uma nova vertente de mercado em torno dessas personalidades da internet e o canal se torna um verdadeiro negócio, pois hoje já se tem ideia do poder que pode ser alcançado na plataforma. Aproveitando dessa espetacularização do eu, nasce cursos particulares criados para preparar aspirantes a celebridades a terem sucesso na plataforma. Como o exemplo demonstrado nas próximas figuras.

Basta digitar no Google a frases do tipo: "Como se tornar um Youtuber?" que aparece mais de 740 mil anúncios com promessas de aumento no número de visualizações e inscritos.

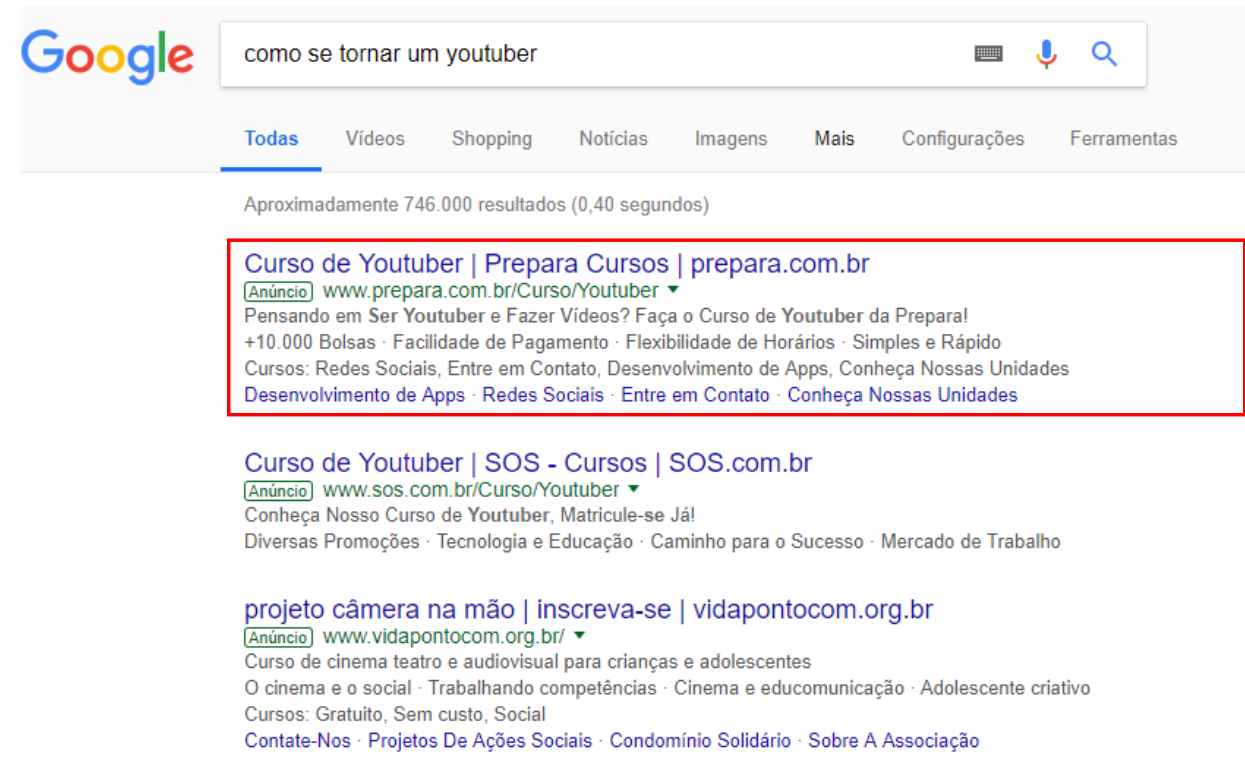

Figura 2 - BUSCA NO GOOGLE SOBRE CURSOS PARA YOUTUBERS 


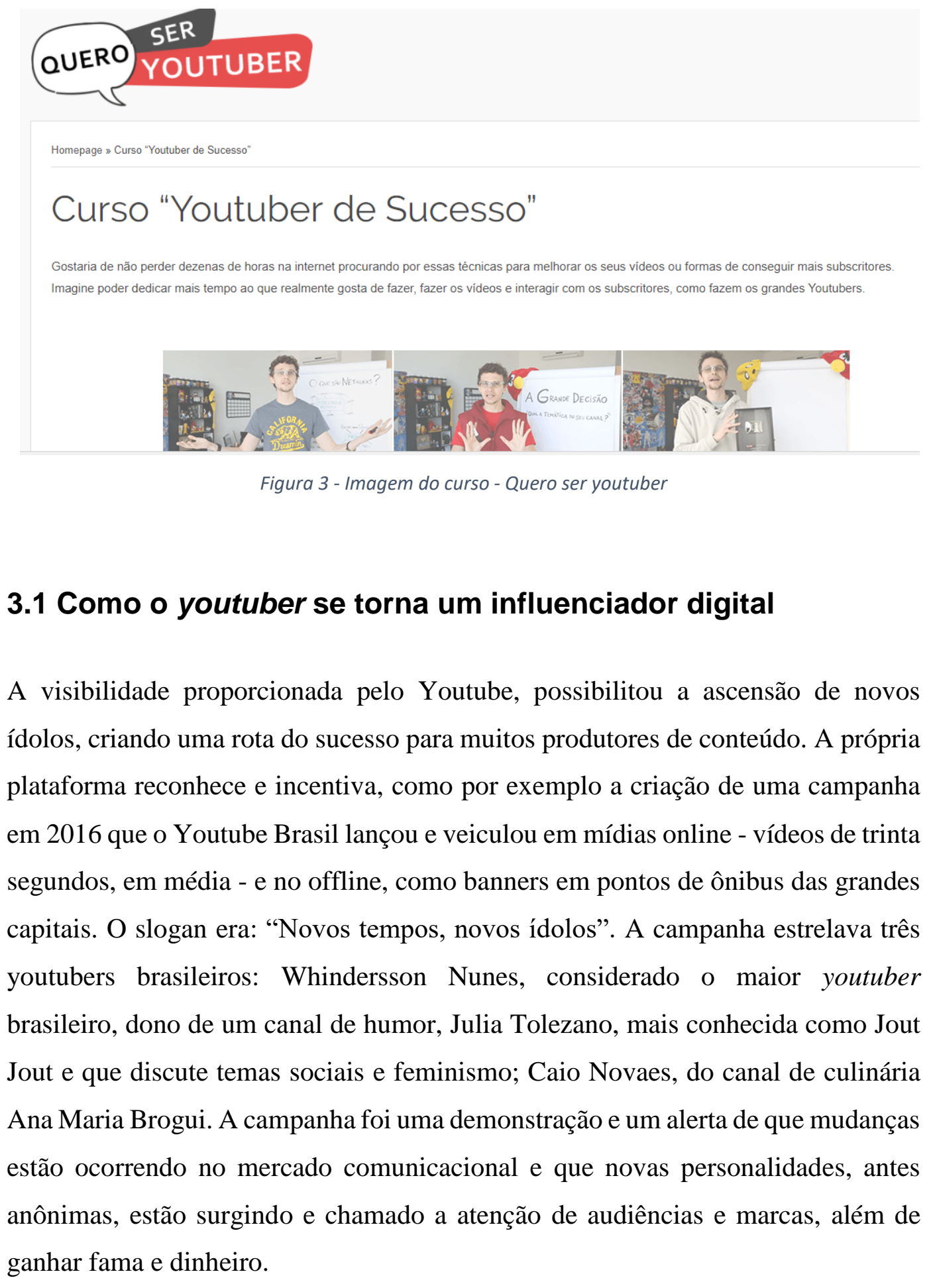




\section{YouTube}

\section{Novos Tempos Novos Ídolos}

Figura 4 - Slogan campanha YouTube - Novos tempos Novos Ídolos

Rosana Hermann, uma importante apresentadora, roteirista e colunista do Estadão, escreveu uma matéria para discutir a relevância da campanha. O título é: "O slogan mais perfeito do momento é do YouTube: "Novos tempos. Novos Ídolos"

Nesses novos tempos queremos ouvir opiniões sobre os fatos do cotidiano, queremos saber o dia a dia de pessoas, queremos ver a realidade, a intimidade [...]. Nesses novos tempos é possível falar para a câmera sem se arrumar toda e passar maquiagem, como JoutJout. Nesses novos tempos é possível ensinar sem parecer um professor acima de você e sim, a seu lado como o Caio. Nesses novos tempos é sucesso falar bobagem que todo mundo fala, com seu sotaque regional e seu quarto bagunçado, como o Whindersson (HERMANN, 2016)

\footnotetext{
${ }^{6}$ Matéria de Rosana Hermann no Estadão online - http://emais.estadao.com.br/blogs/queridoleitor/o-slogan-mais-perfeito-do-momento-e-do-youtube-novos-tempos-novos-idolos/
} 


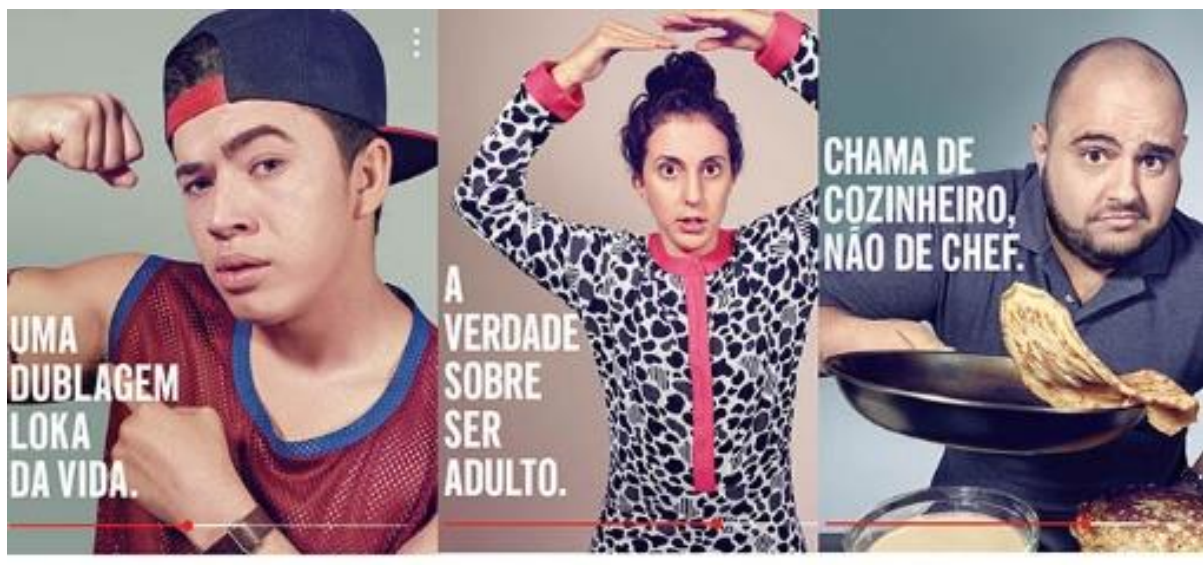

You Tube/WhinderssonNunes You Twhe/JoutJout YouTube/AnaMariaBrogui

Figura 5 - BANNER - CAMPANHA NOVOS TEMPOS NOVOS ÍDOLOS

Por causa da grande exposição à qual são submetidos e o poder de alcance de suas mensagens, os youtubers e demais webcelebridades - passaram a ser identificados enquanto influenciadores digitais. Para Issaaf Karhawi (2016), o influenciador digital é um indivíduo que exerce impacto acima da média num segmento, seja ele grande, pequeno ou mesmo um nicho. É capaz de formar um público fiel e engajado, exercendo influência em alguma medida sobre suas opiniões e atitudes. Em última análise, influencia a tomada de decisão de compra das pessoas que o seguem. Os influenciadores digitais são também chamados de creators pela alta capacidade de produção de conteúdo relevante para seu público.

No que se refere a "influência", em sua definição, é um fenômeno inerente à natureza de grupos de pessoas - e, portanto, muito anterior à internet - porém, o termo "influenciador", hoje, está muito associado a plataformas digitais e a redes sociais. 


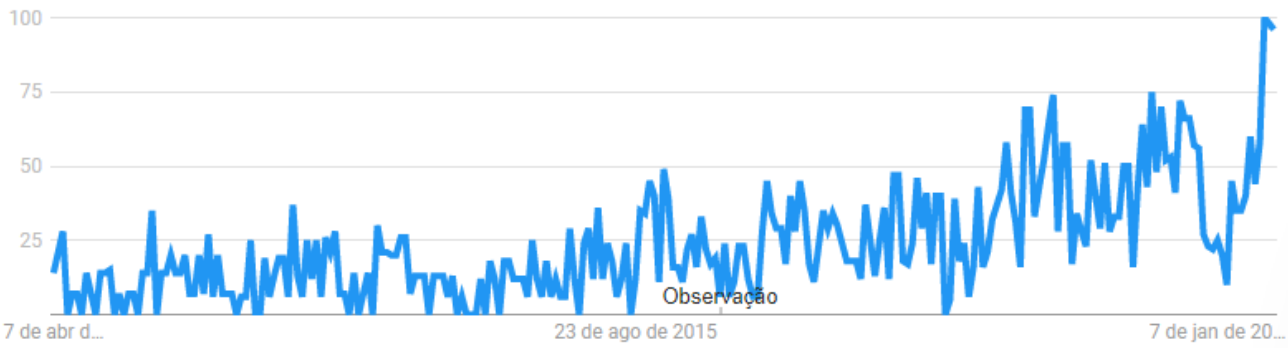

Figura 6 - GOOGLE TRENDS - INFLUENCIADOR

Para a Publicidade o que caracteriza o influenciador digital é o alto desempenho a partir de três pilares: alcance, relevância e ressonância.
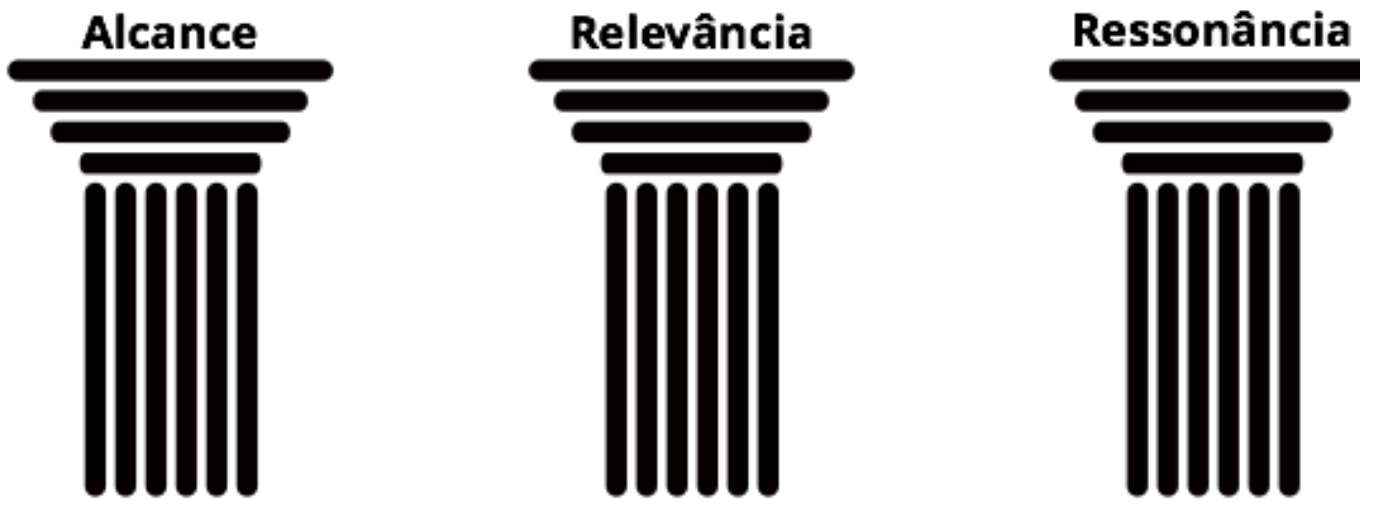

Figura 7 - PILARES PARA IDENTIFICAR INFLUENCIADORES DIGITAIS

Para identificar um influenciador digital, a publicidade combina esses três pilares. Por exemplo, um usuário de rede social que tenha muitos seguidores (alcance), mas não gere engajamento (ressonância) nem tenha relevância no grupo não é um influenciador digital. Da mesma forma, alguém que produza conteúdo altamente relevante, mas tenha apenas 80 seguidores também não é um influenciador digital por causa do baixo alcance.

Para gerar 'alcance', o influenciador precisa primeiro ser relevante e ressonante. Para tanto, conhecer o seu público é fundamental. Ele precisa produzir conteúdo relevante e que vão gerar identificação. O que eles geralmente consomem? Quais canais utilizam para se informar? Quais marcas admiram? Essas são algumas das perguntas que orientam a produção de conteúdo por parte do influenciador. Quando 
o influenciador já está inserido em algum nicho, esse processo é facilitado pois já se sabe o que o público gosta, uma vez que ambos fazem parte de um mesmo grupo. Por exemplo, os criadores do site Jovem Nerd são "jovens nerds" antes de serem influenciadores. Eles entendem e falam a mesma língua dos seus seguidores. Outro fator importante é ser transparente. Mais do que criar conteúdo atrativos e interativos, os influenciadores precisam apostar na transparência! Ou seja, quando algum post é pago ou quando há alguma parceria com certa marca, isso precisa ser indicado. Além disso, não adianta se veicular a uma marca aleatória só pelo dinheiro, isso vai ser percebido pelo público, o que acaba prejudicando a confiança dos mesmos. Diferentemente das celebridades, os influenciadores são mais “atingíveis", eles estão a um clique, a uma mensagem de distância. Nesse sentido, o influenciador precisa estabelecer uma interação continua com os seus seguidores. Ou seja, responder comentários, tirar suas dúvidas, responder a críticas - tudo isso é muito valorizado pelo público. Em resumo, o influenciador digital precisa estabelecer uma comunicação otimizada com o seu grupo.

No mundo e no Brasil, os influenciadores digitais começam a mudar algumas regras do jogo no que se refere a influencia no consumo. Por exemplo: uma marca pode gastar milhões em publicidade na TV para contratar um jogador de futebol e mostrar seu celular resistente a água, enquanto um youtuber famoso pode fazer um vídeo para demonstrar que o celular não cumpre o que promete, o que trará sérios problemas para a marca. Como o contrário também pode acontecer, caso um youtuber seja consumidor de uma marca e resolva fazer um vídeo elogiando-a, praticamente sem custo nenhum a marca ganhará seguidores e possíveis consumidores.

Para Zygmunt Bauman (2008), assim se forma a lógica cíclica da sociedade, onde as pessoas se transformam em mercadorias como se quisessem "se vender", uma espécie de autopromoção por meio do consumo que as torna atraentes e desejadas. Desta forma, ao mesmo tempo em que promovem as mercadorias, também são promovidas por elas.

Num momento em que as pessoas consomem cada vez mais conteúdo em vídeo pela internet, o interesse por esses produtores de conteúdo tem crescido bastante pelas marcas. Atentas a essas mudanças, temos observado diversas ações de 
merchandising com influenciadores digitais. A intensão dessas empresas é aproveitar o carisma e irreverencia dessas pessoas, e principalmente a sua base de fãs que já está consolidada, que se engaja e se relaciona profundamente com o conteúdo. Quando as empresas utilizam desse meio, não precisam fazer grandes esforços para acertar o consumidor em cheio. As marcas perceberam o movimento do consumidor de não "engolir" mais a propaganda tradicional, dessa forma procuraram se conectar e interagir com as celebridades digitais, se apropriando disso como uma estratégia de marketing.

Muitas pessoas, principalmente os mais jovens se inspiram nas suas personalidades digitais favoritas e as utilizam como referência para tudo, confiam nos influenciadores e querem estar cada vez mais próximos deles. A maior parte desse universo é constituída de nativos digitais e os influenciadores falam a "mesma língua", o que facilita muito o processo de comunicação e consequente divulgação de algum produto ou serviço.

No quarto capitulo deste trabalho, tratarei de compreender um pouco mais sobre como um youtuber ganha status de influenciador digital. Para tanto, me debrucei durante seis meses sobre o canal de Whindersson Nunes na plataforma do YouTube. Segundo uma pesquisa realizada pela Google em parceria com o Instituto Provokers, Whindersson é a personalidade mais influente do Brasil em 2017.

\section{O Lampião do YouTube - Um fenômeno chamado Whindersson}

Fila virando o quarteirão olho para o relógio e ainda falta meia hora para entrarmos. Observo na minha frente um grupo de jovens que conversam, excitados, na espera para entrar em uma casa de espetáculos na Rua Augusta em São Paulo. Um dos adolescentes diz: "Acho que o meu coração vai sair pela boca”. Um outro garoto ao lado gaba-se: "Conheço o Whindersson desde quando ele tinha pouco mais de 10 mil inscritos no canal. Esses jovens estavam ansiosos ver o seu ídolo e, eu não tinha noção da potência do cara que estava aguardando para assistir. Esses jovens estavam falando de Whindersson Nunes, humorista piauiense de 23 anos - hoje o maior fenômeno individual brasileiro do YouTube. 
Entramos! Procuro meu lugar e percebo que escolhi uma visão privilegiada do Palco. Estou na bancada direita. Onde tem cadeiras. Olho pra baixo e vejo na plateia pessoas de todas as idades. Mas em maior concentração são jovens de 16 a 20 e poucos anos. Acho que sou mais velha por aqui. Mais alguns minutos e a luz apaga. A sessão de stand up vai começar. De um clarão no palco ele surge, a plateia perde o chão. Garotos com o mesmo corte e cor de cabelo do comediante - a franja alisada jogada para a direita — se empurram para chegar perto dele primeiro. Observo algumas garotas vestidas com camisetas onde se lê "Te amo Whin" se jogam em busca de um abraço ou, talvez, de um beijo. Alguns adultos se esgueiram entre a molecada para tirar uma selfie, quem sabe gravar um vídeo rápido, para tirar de descolados postando em suas redes sociais. Outro grupo se destaca ao exibir blusas com os dizeres: "Fazemos parte dos 22 milhões".

Foi assim o meu primeiro contato com o Whindersson Nunes. Era começo de 2017. O convite para assistir ao show de stand up veio de uma amiga que fui visitar em São Paulo e que era fã do garoto desde que ele tinha 17 anos. Acho que eu estava meio atrasada. Não fazia ideia de que ele era um fenômeno da internet. $\mathrm{Na}$ apresentação do stand up ele me pareceu um garoto comum, mas com um senso de humor fora do comum, muito inteligente, com uma língua afiada e rápida. Tirava piada de assuntos do cotidiano. Saindo do show fiquei muito curiosa em saber mais sobre o tal do Whindersson e comecei a pesquisar a vida dele. O primeiro vídeo que assisti foi recomendação da minha amiga fã. A parodia chamada: "Alô vó, tô reprovado". Antes de dar o play, fiquei observando as métricas do YouTube, (uma mania de quem trabalha com publicidade). O que me impressionou foi a quantidade de visualizações. 10 Milhões. Mais de 20 mil comentários, 600 mil interações no botão gostei. Esse vídeo é um viral ${ }^{7}$ famoso que se tornou uma das marcas do comediante. Nunca tinha visto uma pessoa ter tantos números em um vídeo caseiro. Mas esses números eram baixos perto de outros que eu ainda viria descobrir.

\footnotetext{
${ }^{7}$ Viral é um termo que surgiu junto com o crescimento do número de usuários de blogs e redes sociais na internet. A palavra é utilizada para designar os conteúdos que acabam sendo divulgados por muitas pessoas e ganham repercussão (muitas vezes inesperada) na web. 0 termo é relacionado a palavra vírus (de computador ou doença), já que as pessoas chegam a compartilhar o conteúdo viral quase que inconscientemente. A palavra viral deu origem a outros termos como viralizar, viralizou e efeito viral (utilizado pelo Facebook para mensurar o quanto um conteúdo de uma página foi compartilhado).
} 
Ex-ajudante de garçom, Whindersson Nunes Batista surgiu na internet compartilhando gravações engraçadinhas, filmadas em seu quarto com uma câmera emprestada de uma amiga. Tem origem humilde, nasceu no seio de uma família de classe média baixa que morava em Palmeira do Piauí interior do Piauí.

Ele teve uma vontade de criar um canal no Youtube. Não tinha grana pra uma câmera, pegou a que estava por perto e funcionava. Fez o primeiro vídeo. O segundo. O terceiro. O quarto. O quinto. Recebeu dez inscritos. Fez o sexto, o sétimo, o oitavo. Recebeu mais trinta inscritos. Manteve a frequência, aumentou a quantidade, não melhorou o equipamento. Um ano se passou. Dois. Três. Pensou em outros formatos de vídeo, se inovou, se superou. Fez o vídeo número cem com a mesma dedicação com a qual fez o primeiro. Faz vídeo para doze milhões de pessoas com a mesma dedicação com a qual fazia para vinte. Sorte? Talvez um pouco. Mas deixa eu te contar um segredo: depois de anos de estrada, qualquer um esbarra num momento de sorte. Você não esbarrou porque não tentou. Não deu nem tempo. (João Doederlein. 2016 - YOUPIX)

Atualmente, o canal de Whindersson é o segundo no ranking do YouTube em número de inscritos (28 milhões), mas é o primeiro em influencia segundo o site Socialblade ${ }^{8}$.

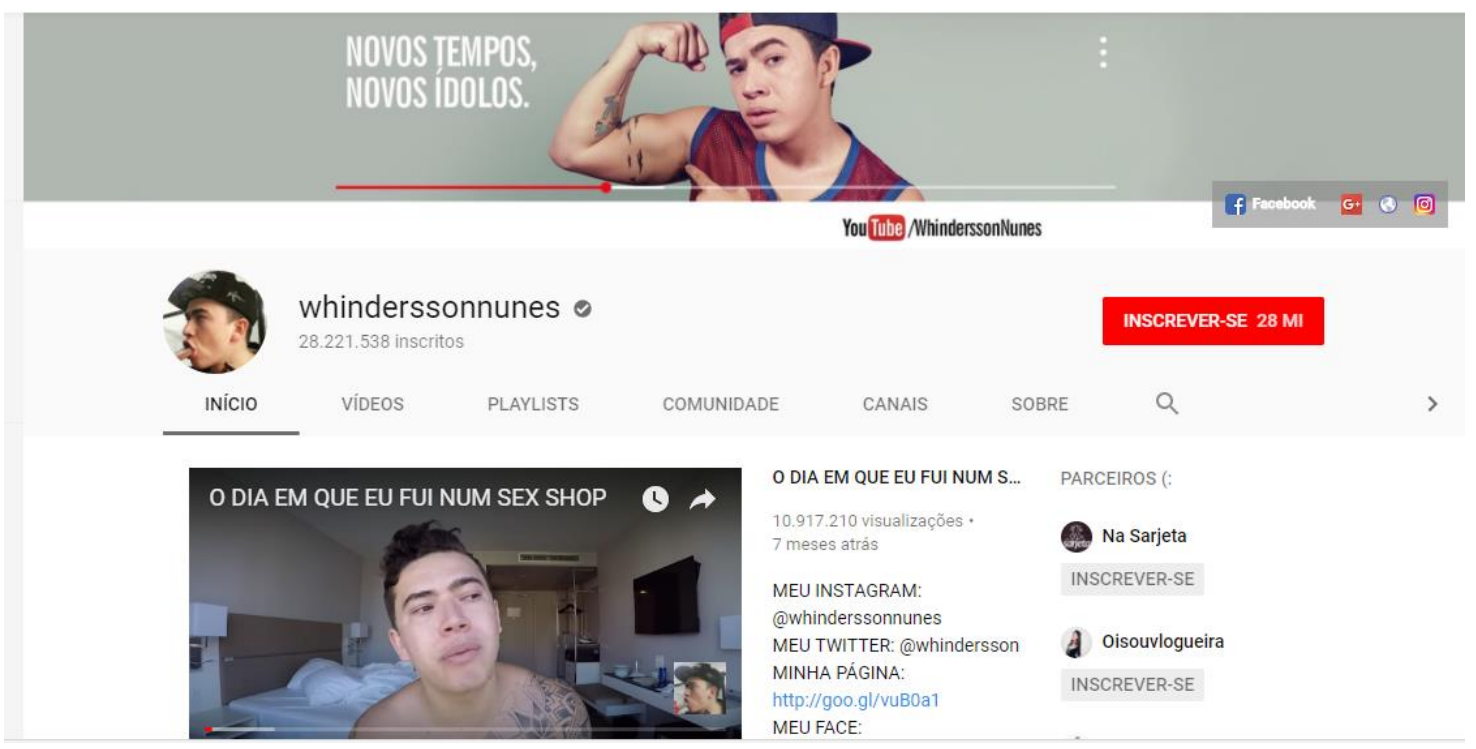

Figura 8 - Canal de Whindersson Nunes no YouTube

\footnotetext{
${ }^{8}$ Segundo o site https://socialblade.com/youtube/top/country/br/mostsubscribed - Whinderson é o segundo youtuber em número de inscritos no Brasil.
} 
O vídeo mais assistido do canal é a paródia intitulada QUAL É A SENHA DO WIFI - Paródia Adele - Hello que ultrapassa sessenta milhões de visualizações. Além de fazer sucesso no YouTube, também faz como ator e stand-up commedy. Em 2017 participou do seu segundo filme - "Os Penetras 2" e, também em 2017, se juntou com outros grandes youtubers, entre eles: Kéfera Buchmann, Christian Figueiredo e Rafinha Bastos para estrelar o seu primeiro filme "Internet - O Filme" cujo o enredo é uma convenção de youtubers, onde os personagens entram em vários conflitos uma vez que todos eles estão em busca da fama a qualquer preço.

Durante seis meses assistindo e acompanhando os canais sociais de Whindersson, principalmente o seu canal no YouTube, a plataforma estudada neste trabalho, foi possível observar que o sucesso do comediante se baseia em três pilares importantes, que são: comunicação simples, cenários e figurinos simples e pouca edição dos vídeos.

Ao contrário de famosos youtubers ${ }^{9}$ e instagramers ${ }^{10}$, Whindersson foge dos principais estereótipos: faz os vídeos $90 \%$ das vezes sem camisa, com um boné virado para trás ou com os cabelos desgrenhados, com uma bermuda, descalço ou chinelo de dedos. O cenário é sempre um quarto que pode variar muito, pois o youtuber viaja com frequência. A cama do quarto está sempre por fazer. Uma bagunça aparente com malas, lenções e objetos do cotidiano do autor. As vezes o youtuber utiliza a sala de estar da sua casa como cenário, mas isso não ocorre com a mesma frequência que os quartos. Praticamente todo o início do vídeo tem sempre uma "dancinha"!

Com mais ou menos 300 vídeos postados na plataforma (média de 10 a 12 minutos cada), procurei assisti pelo menos 15 diferentes, do início da carreira até março de 2018. Obviamente, não conseguirei expor analiticamente todos os vídeos aqui, por isso, escolhi um vídeo por ser emblemático e porque o youtuber faz a propaganda de um produto que pertence a uma marca mundialmente famosa.

\footnotetext{
${ }^{9}$ Youtubers: A definição dada para a palavra Youtuber, segundo verbete do Oxford English Dicionary, é "um usuário frequente do site de compartilhamento de vídeos YouTube, especialmente alguém que produz e aparece em vídeos no site". Fonte: www.oed.com 10 Instagramers: aquele que posta no Instagram - plataforma de álbuns digitais de fotografias e vídeos.
} 
Metodologicamente, a etnografia digital me permite ser analítica e descritiva, mas temendo que seja um assunto denso e difícil de expor, pois trata-se de um vídeo e a descrição densa do mesmo não imprimiria, mesmo que sendo detalhista, toda a dinâmica que essa mídia propõe. Pensando nisso, dividi a analise em três formas: A primeira é a análise da forma de como Whindersson se apresenta para o público em geral. A segunda é a sua relação com a marca e, por último, a sua relação/interação com os seus seguidores. O vídeo escolhido foi: Solteiro ou Namorando, publicado em maio de 2017 no seu canal no YouTube.

\subsection{Sem camisa no quarto bagunçado: Da apresentação para o publico}

Os primeiros 34 segundos do vídeo o youtuber aparece de frente a câmera fazendo uma performance dançante da música - Halo da cantora americana Beyonce. Whindersson dança explorando alguns cantos do cenário que como os outros vídeos é um quarto (no canto esquerdo do vídeo um violão sobre uma cama, uma mala de roupas na cor azul, um guarda-roupas de madeira com portas de vidro, uma porta branca ao fundo. Já no canto direito do vídeo uma estante com alguns objetos pessoais, um par de botas em cima de uma escrivaninha branca de quatro gavetas e mais alguns objetos pessoais por ali.

Em um primeiro momento até o (00:35) do vídeo, Whindersson aparece sem camisa, bermuda preta, chinelo da marca Havaiana cinza. Seus cabelos estão soltos e com uma cor do tipo loiro. Tem uma pequena franja que cobre o rosto.

Em um segundo momento do vídeo, (a partir do 00:36) o youtuber aparece com um boné camuflado tipo exército virado para trás, mas continua com bermuda preta e chinelos. Agora não aparente no vídeo.

O youtuber exibe algumas tatuagens que ocupam os dois braços. Uma começa do peito esquerdo e se espalha até a metade do braço também esquerdo - uma espécie de tatuagem tribal com flores geométricas. Uma outra tatuagem aparece no braço direito - um desenho tipo "filtro dos sonhos". No antebraço direito aparece Mãe Pai e um coração vermelho no meio das duas palavras. 


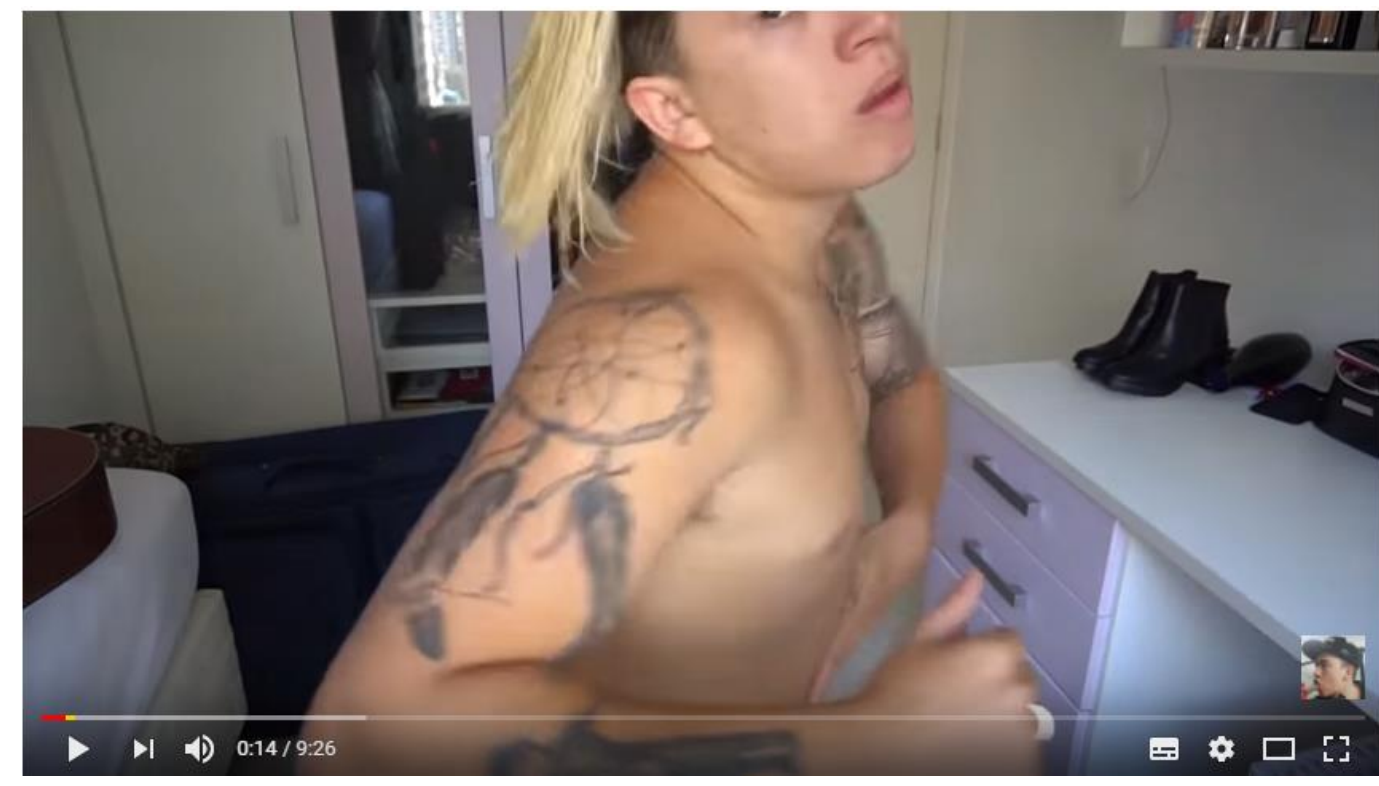

Figura 9 - VIDEO SOLTEIRO OU NAMORANDO - WHINDERSSON NUNES - RECORTE 0:14

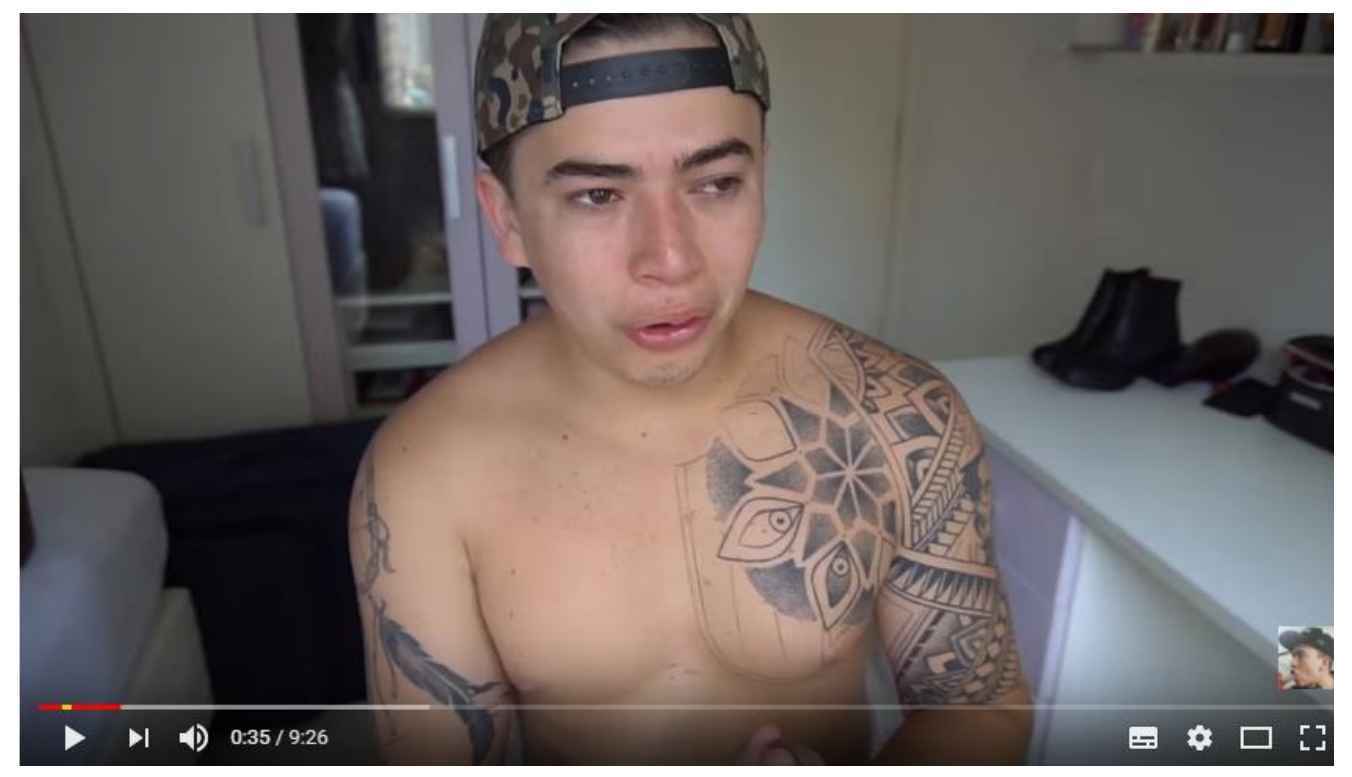

Figura 10 - VIDEO SOLTEIRO OU NAMORANDO - RECORTE 00:35

Nota-se que o youtuber escolhe temas do seu cotidiano e principalmente aqueles que atraem de alguma maneira os seus seguidores.

"Eu já fui muito povão, só que agora, como meus temas são variados, volta e meia pega uma galera diferente. Por exemplo: meu público é dos 18 aos 27, a maior parte. A segunda maior parte é dos 28 aos 34, e a terceira é de 13 aos 17. Então tem uma galera 
de todo jeito aí, entendeu? É que eu não faço muito vídeo sobre a mesma coisa. Tenho vídeo sobre escola, aí pega a garotada. Tenho vídeo sobre doação de sangue, e aí pega a galera da medicina. Tenho vídeo sobre barba, aí pega homens". (WHINDERSSON NUNES - REVISTA TRIP 270 ).

A Google juntamente com o Instituto Provokers, publicou no ano de 2017, pelo terceiro ano consecutivo, uma pesquisa chamada: Os Influenciadores - Quem Brilha na Tela dos Brasileiros". A pesquisa entrevistou 2.500 pessoas no universo de 14 a 34 anos e os resultados demonstraram que o consumo de conteúdo no YouTube vai muito além dos jovens. A pesquisa também revelou que os atributos valorizados pelo público em geral são: originalidade, senso de humor, autenticidade e inteligência na discussão do tema. Traços esses que deram o título de maior influenciador brasileiro para Whindersson Nunes. O youtuber ficou com a nota de 68,8 em um score que varia de 0 a 100. (vide ranking na Figura 3).

\section{Influenciadores 2017 - Ranking}

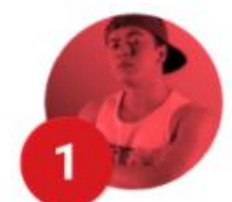

68,8

Whindersson Nunes

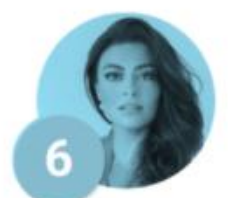

47,2

Juliana Paes

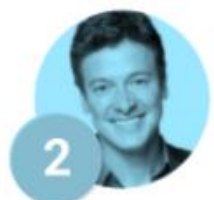

58,9

Rodrigo Faro

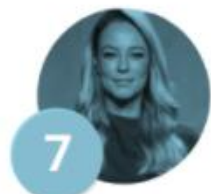

45,8

Paolla Oliveira
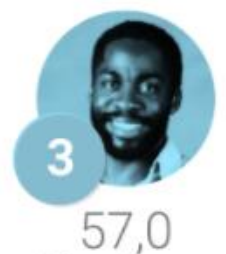

Lázaro Ramos

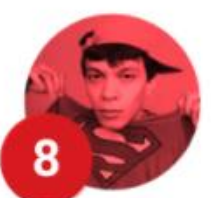

41,2

Julio Cocielo

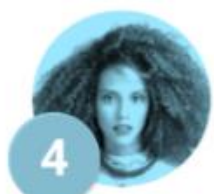

54,2

Taís Araújo

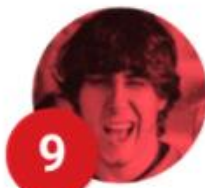

38,7

Felipe Castanhari

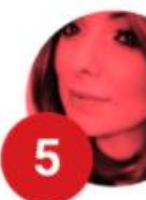

51,6

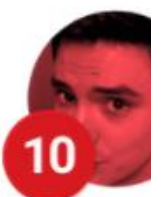

33,

Felipe $\mathrm{N}$

Figura 11 - RANKING DA PESQUISA - OS INFLUENCIADORES - QUEM BRILHA NA TELA DOS BRASILEIROS 2017

O tema do vídeo analisado - Solteiro ou Namorando - como tantos outros vídeos, provaram a habilidade de Whindersson em agradar seus seguidores. Solteiro ou Namorando já se tornou um viral com um número de visualizações relativamente alto (11.701.456), um outro número que chama bastante atenção é o do indicador "Gostei" 
(1.532.453). Outro indicador importante, que analisamos com maior profundidade a partir da leitura e classificação, foram os comentários em neutros e positivos (26.728) ${ }^{11}$ conforme gráfico abaixo:

\section{Sentimento}

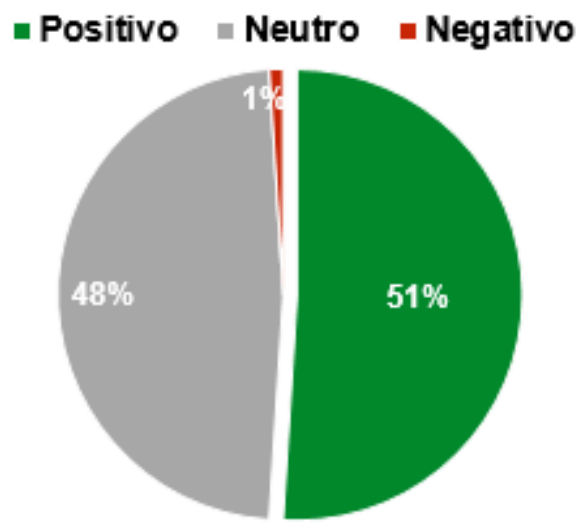

Figura 12 - Analise de sentimento dos comentários sobre o vídeo - Solteiro ou Namorando

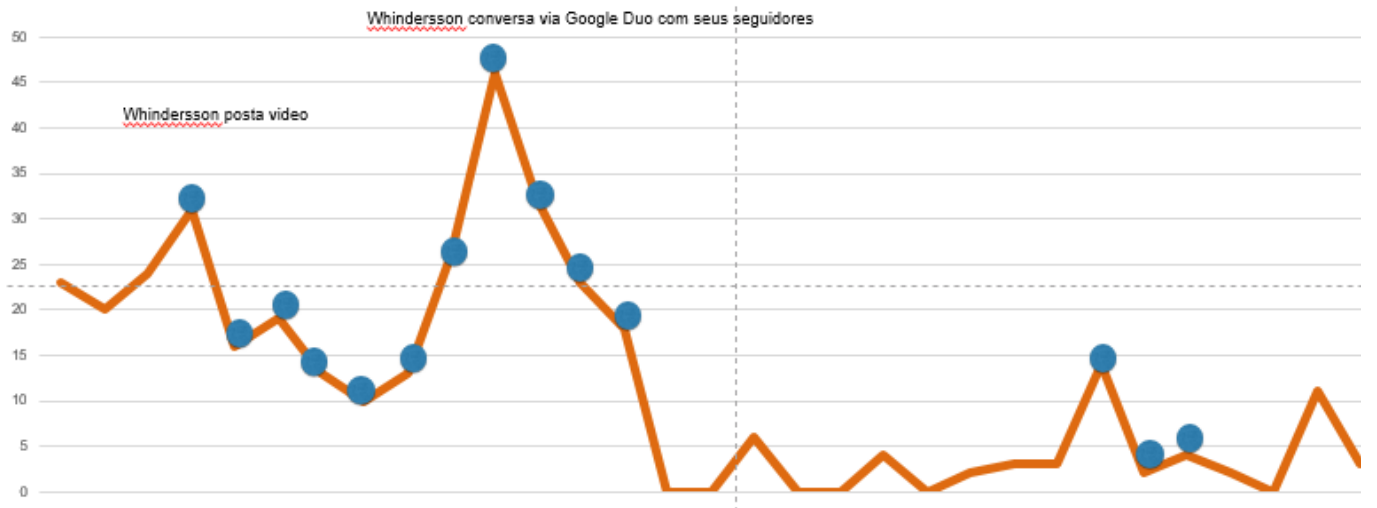

Figura 13 - Gráfico que representa o número de comentários no vídeo - primeiras horas de postagem

\subsection{O vídeo Solteiro ou Namorando}

Whindersson descreve muito espontaneamente o início da sua manhã com a namorada Luisa Sonsa. O assunto é relativamente pessoal. A sua namorada teve um sonho na noite anterior e, ao acorda-la com um abraço matinal ele percebe que ela está muito nervosa. Quando o mesmo a indaga para saber o que ele fez para ela estar tão nervosa, percebe

\footnotetext{
${ }^{11}$ Tanto o número de visualizações, as que clicaram no botão gostei e os comentários do vídeo foram contabilizadas até a data de 18.12.2017.
} 
que na verdade ela está nervosa com alguma coisa que ele fez no sonho e não na vida real. Daí em diante o youtuber explica ao expectador o tema central do vídeo que são as diferenças de estar solteiro ou namorando. Whindersson faz uma encenação da conversa para explicar o expectador.

Ao perguntar para o Whindersson se ele conhecia alguma Jessica. O jovem diz que não conhece nenhuma Jessica e os dois começam a discutir. (A partir do 1:24). Na encenação o youtuber utiliza cortes que aparece como ele próprio Whindersson - cabelos presos pelo boné camuflado exército e hora ele faz o papel da namorada Luisa, com os cabelos soltos e loiros. A imitação de uma voz feminina dá o tom a cena.
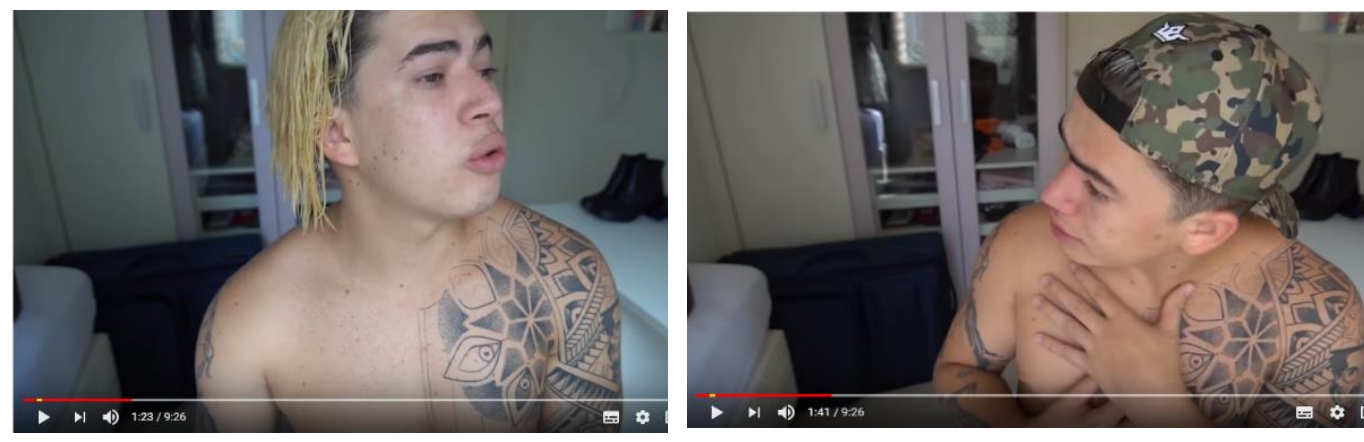

Figura 14 E 12 - IMITAÇÃO DO CASAL LUISA SONSA E WHINDERSSON NUNES

A partir do (2:10), Whindersson faz uma observação de que quando a pessoa está namorando precisa se privar de algumas situações para não criar problemas dentro do namoro. E desse ponto em diante, ele dá exemplos de contextos diferentes de quando uma pessoa está namorando de quando está solteiro. Em um dos exemplos ele cita: como as pessoas mudam ao falar pelo celular com amigos e, como as mulheres ficam nervosas quando estão com TPM.

Analisando os comentários sobre o vídeo percebemos que 48\% do público se identificou de alguma maneira com o assunto conforme podemos observar na nuvem de palavras composta pelas principais expressões. 


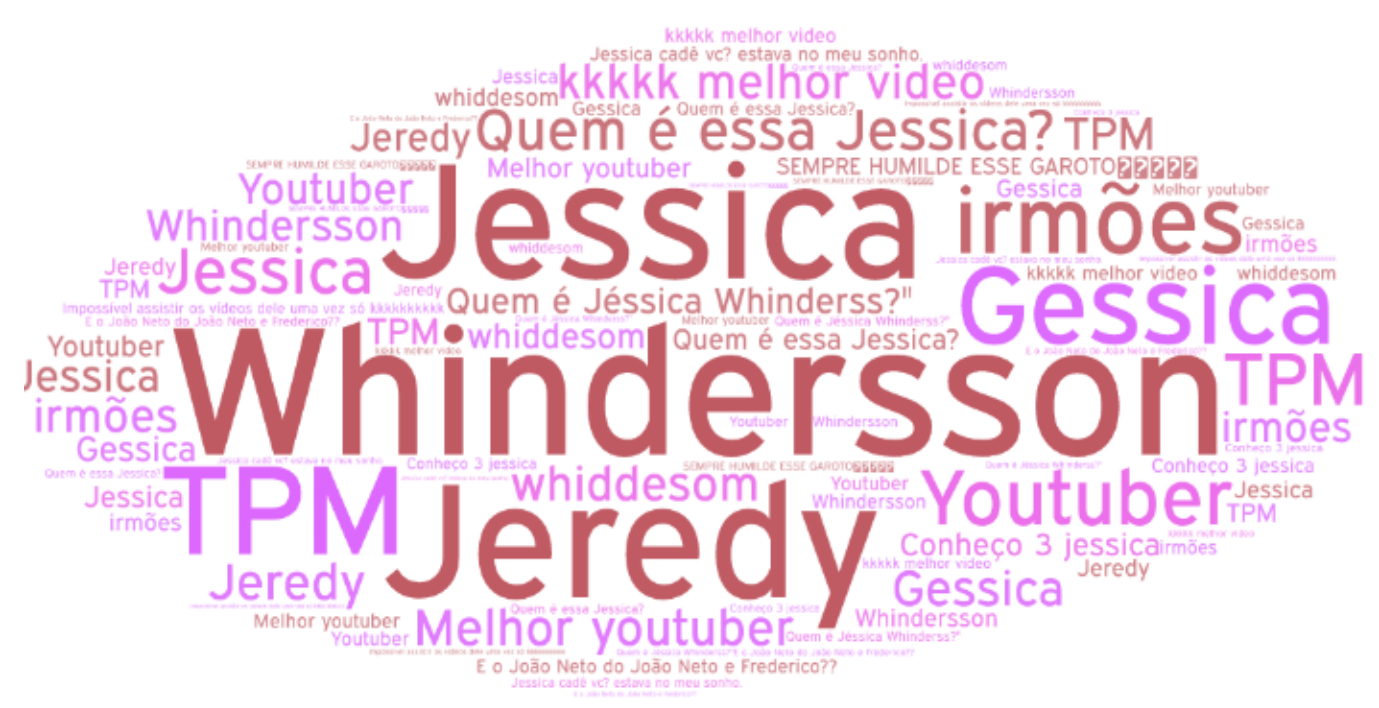

Figura 15 - Nuvem de correspondência - comentários vídeo - Solteiro ou Namorando

Mas, sem dúvida o ponto alto do vídeo é no minuto (5:35). É neste momento que Whindersson recebe uma ligação no celular pelo aplicativo Google Duo ${ }^{12}$. Ele faz questão de mostrar ao público a ligação. Com um gesto mostra que o seu amigo J. Neto está do outro lado da linha. Essa é a deixa para o youtuber falar e fazer a propaganda do aplicativo de videoconferência do Google.

\subsection{Com o Google Duo é cara a cara - A relação com a marca}

Whindersson é um influenciador de várias marcas. Atualmente é garoto propaganda de uma importante operadora de telefonia. Já fez comerciais para uma rede de fastfoods brasileira que até sanduiche fez em sua homenagem e, também, protagonizou um comercial de famoso título de capitalização que gera prêmios.

Como garoto propagando, Whindersson passa para o público mais do que uma simpatia pelas marcas de que fala, ele passa credibilidade real através do seu discurso espontâneo. Por isso, tem protagonizado na mídia como embaixador de várias marcas. Em 2017 foi convidado pela Google para promover a popularização do um aplicativo de chamadas de vídeo. O aplicativo é especial, pois diferente dos outros aplicativos de vídeo conferencia do mercado, o da Google possui diversas funções interessantes, incluindo a "Knock

\footnotetext{
12 Google Duo é um aplicativo móvel de vídeo chat desenvolvido pelo Google, disponível nos sistemas operacionais Android e iOS.

Google Duo permite aos usuários fazer chamadas de vídeo em alta definição. É otimizado para redes de baixa largura de banda, ou seja, internet mais lenta. A criptografia de ponta a ponta é habilitada por padrão. O Duo é baseado em números de telefone, permitindo que os usuários chamem alguém de sua lista de contatos. $\mathrm{O}$ aplicativo muda automaticamente entre redes de WiFi e redes celulares. O recurso "Knock Knock" permite que os usuários vejam uma visualização ao vivo da pessoa que está ligando antes de atender. A atualização de abril de 2017 permitiu com que usuários em todo o mundo possam fazer chamadas somente de áudio.
} 
Knock". Trata-se de uma tecnologia que permite a transmissão da imagem de quem está fazendo a ligação ao vivo antes mesmo da ligação ser atendida. Dessa forma, é possível ver a expressão da pessoa que está ligando para você, por exemplo, e como o próprio Whindersson diz em seu vídeo "saber se é importante ou não". O Vídeo analisado no presente trabalho - Solteiro ou Namorando - é o mesmo que o Whindersson usa "sutilmente" para falar do novo produto da Google - o Google Duo.

Durante o tempo que Whindersson fala sobre o aplicativo, parece ser espontâneo. Fala como se já usasse o produto no seu dia a dia. Ele não dá muitos detalhes do produto, mas fala da funcionalidade especial que é Knock Knock que as vantagens de ver antes mesmo de atender a ligação a imagem da pessoa que está do outro lado ao vivo.

\section{4 - \#WhinderssonResponde}

Whindersson, no final de todos os seus vídeos, sempre convida sua audiência a interagir com o conteúdo de alguma maneira, seja nos comentários do YouTube ou em outras redes sociais. Ele pede que seus fãs comentem se já passaram ou não por uma situação semelhante e também pede que eles compartilhem o conteúdo com amigos que tenham passado por algo semelhante. Esse pedido explícito, acompanhado do pedido de inscrição e like no canal, faz as pessoas agirem dessa forma, contribuindo para aumentar o engajamento geral do canal e para que Whindersson se torne conhecido por mais gente: só em março seu conteúdo foi compartilhado mais de 290 mil vezes.

No vídeo Solteiro ou Namorando, ele vai além. Para popularizar o uso do aplicativo da Google, o Whindersson convida seus seguidores a ligar pra ele. Ele anuncia que na segunda-feira (05) das $11 \mathrm{~h}$ às 16 qualquer pessoa pode ligar para seu celular (11 99541-7531) que ele atenderá de forma aleatória as videochamadas.

A Google e o próprio Whindersson não disponibilizaram nenhuma estatística para que possamos entender se a campanha foi um sucesso. Contudo, podemos imaginar que muitos usuários fizeram a ligação para o Whindersson já que na análise dos comentários do vídeo, foi possível identificar menções com intensão de uso do aplicativo Google Duo. 


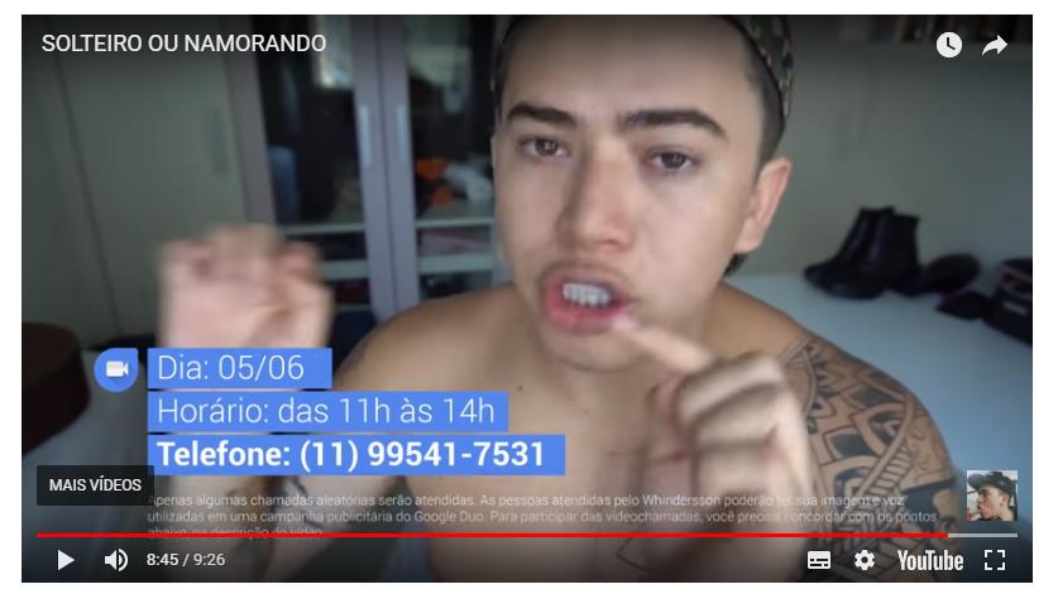

Figura 16 - Convite para fazer a ligação

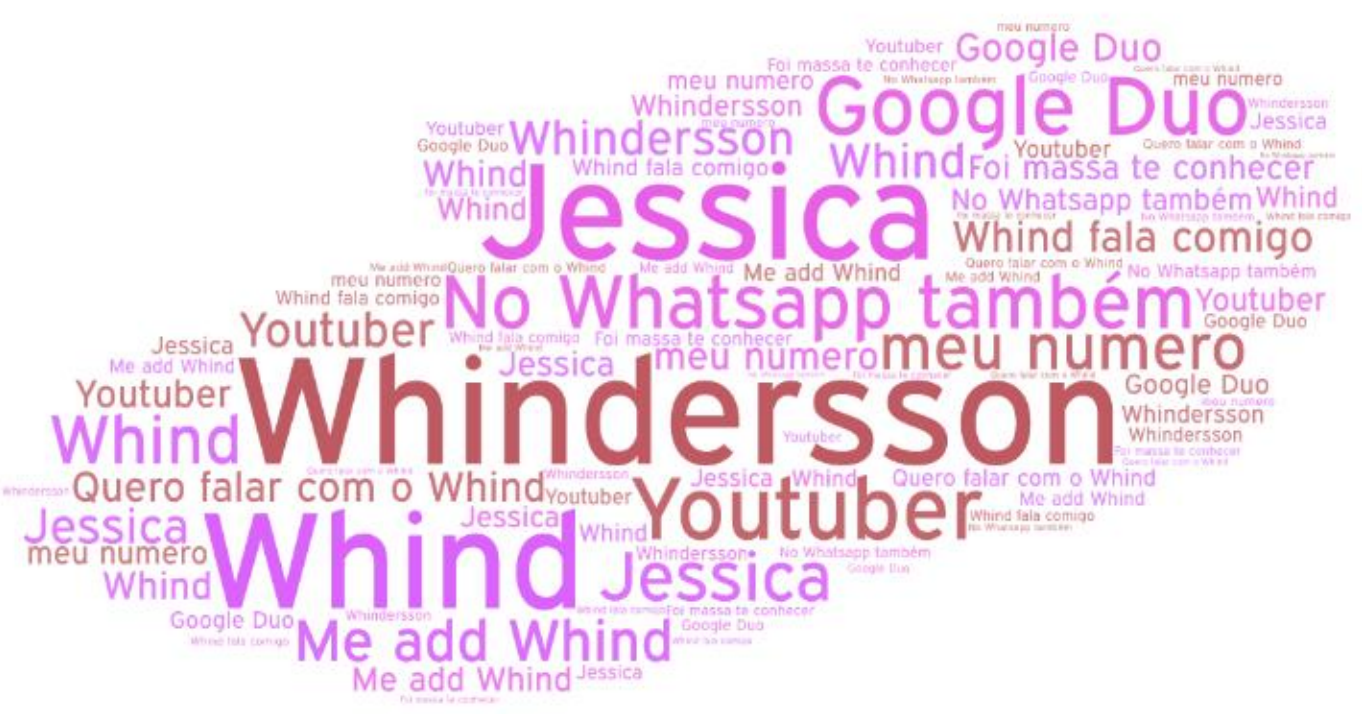

Figura 17 - Nuvem de correspondencia - Comentarios sobre o Google Duo 


\section{Conclusão}

O YouTube como plataforma de princípios democráticos que valoriza o compartilhamento da informação e, incentiva a auto-expressão e a experimentação da criatividade, tem conseguido cumprir o seu objetivo de forma honesta e admirável - meu ponto de vista. Mesmo com toda a sua lógica comercial baseada na publicidade, inclusive responsável pela manutenção da plataforma e de seus criadores, ele foi fundamental na democratização, na qualidade e na distribuição gratuita de conteúdos audiovisuais. Com o seu alcance global, possibilitou que pessoas comuns um poder que antes só pertencia à grande mídia. E, por consequência remodelou as formas como a sociedade em rede consome e produz em múltiplos aspectos.

Parafraseando o sociólogo Manuel Castells: o papel da sociedade em rede era o de mudar os valores sobre os quais a sociedade está organizada. "O que as tecnologias fazem é proporcionar um amplo leque de possibilidades. O que acontece, depois, com as tecnologias, depende do que acontece na sociedade ".

Em linhas gerais, a presente monografia se propôs a trazer para a academia questionamentos, reflexões e os dilemas modernos da Comunicação, nos quais os youtubers e influenciadores digitais ocupam lugar de destaque. 


\section{Bibliografia}

BAUMAN, Zygmunt. Vida para consumo: a transformação daspessoas em mercadoria. Rio de Janeiro: Zahar (2008).

BUGESS, Jean GREEN, Joshua A cauda longa: do mercado de massa para o mercado de nicho. Rio de Janeiro: Campus. (2006).

BURGESS, Jean; GREEN, Joshua. YouTube: digital media and society series. Malden: Polity Press, 2009.

BRASIL. Secretaria de Comunicação Social. Pesquisa Brasileira de Mídia 2015. Brasília, 2015.

BRASIL. Secretaria de Comunicação Social. Pesquisa Brasileira de Mídia 2016. Brasília, 2016.

CASTELLS, Manuel. A sociedade em rede. Paz e Terra, São Paulo, 1999. . A galáxia da Internet.. Rio de Janeiro, Jorge Zahar. 2003.

DEBORD, Guy. A sociedade do espetáculo. 3a reimpr. Rio deJaneiro: Contraponto. (2002).

GOOGLE BRASIL. Pesquisa revela a intimidade dos brasileiros com o Youtube. 2015. Disponível em: <https://www.thinkwithgoogle.com/int//ptbr/articles/intimidade-dos-brasileiros-com-youtube.html>. Acesso em: 22 março de 2018. 
HALL, Stuart. A identidade cultural na pós-modernidade. Rio de Janeiro: DP\& A. (1998).

HOLMBOM, Mattias. The YouTuber: a qualitative study of popular content creators. Suécia: Umeå universitet, 2015. Disponível em: <http://umu.divaportal.org/smash/get/diva2:825044/FULLTEXT01.pdf. . . Acesso em: 18 de março de 2018.

HERMANN, Rosana. O slogan mais perfeito do momento é do YouTube: "Novos tempos. Novos Ídolos". Estadão, São Paulo, 21 maio 2016. Disponível em: < http://emais.estadao.com.br/blogs/querido-leitor/oslogan-mais-perfeito-do-momento-e-do-youtube-novos-tempos-novosidolos/>. Acesso em: 22 de março de 2018.

GOOGLE BRASIL. Pesquisa revela a intimidade dos brasileiros com o Youtube. 2015. Disponível em: <https://www.thinkwithgoogle.com/int//ptbr/articles/intimidade-dos-brasileiros-com-youtube.html>. Acesso em: 22 março de 2018.

JENKINS, Henry. Cultura da Convergência. São Paulo: Aleph, 2013.

KARHAWI, Issaaf. Influenciadores digitais: o Eu como mercadoria. In: SAAD, Elizabeth; SILVEIRA, Stefanie Carlan da. (Org.). Tendências em Comunicação Digital. 21. ed. São Paulo: ECA/USP, 2016. p. 38-58. Disponível em: $<$ http://www.livrosabertos.sibi.usp.br/portaldelivrosUSP/catalog/download/ 87/75/365-1 ? inline=1 >. Acesso em: 19 março de 2018.

KOZINETS, R.V. On netnography: Initial reflections on consumer research investigations of cyberculture, Advances in Consumer Research, (pg. 25, 366-371). (1998).

KOZINETS, R.V. The field behind the screen: Using netnography for marketing research in online communities, Journal of Marketing Research, (pg. 39, 61-72). (2002) 
LEVY, Pierre. O que é o virtual. São Paulo: Ed. 34, 1996.

. As tecnologias da inteligência. São Paulo: Ed. 34. 1997.

. A inteligência coletiva. São Paulo: Edições Loyola, 1998.

. A máquina universo. Porto Alegre: ArtMed, 1998.

. Cibercultura. São Paulo: Ed. 34, 1999;

LIPOVETSKY, Gilles. A era do vazio: ensaios sobre o indivi-dualismo contemporâneo. Lisboa: Relógio D"Água. (1989).

SIBILIA, Paula. O show do eu: a intimidade como espetáculo. Rio de Janeiro: Nova Fronteira, 2008.

\section{AUDIOVISUAIS}

NUNES, Whindersson. Alô vó, tô reprovado (OFICIAL) PARÓDIA "Alô vó, Tô estourado Forró Safado Clip oficial"

$<$ https://www.youtube.com/watch?v=0080oWPWbls $>$ Acessado em 12 de março de 2018.

NUNES, Whindersson. QUAL É A SENHA DO WIFI - Paródia Adele Hello < https://www.youtube.com/watch?v=tWs1E2BfNZE $>$. Acessado em 12 de março de 2018.

NUNES, Whindersson. Solteiro ou namorando $<$ https://www.youtube.com/watch?v=Arp6nnGs6il> Acessado em 12 de março de 2018.

NUNES, Whindersson. Saudades de antigamente < https://www.youtube.com/watch?v=Da4wic7G7OE> Acessado em 13 de março de 2018. 